Original article

\title{
Synthesis, antiproliferative activity, and mechanism of action of a series of 2-\{[(2E)-3-phenylprop-2-enoyl ]amino\}benzamides
}

\author{
Demetrio Raffa $^{\mathrm{a}, *}$, Benedetta Maggio ${ }^{\mathrm{a}}$, Fabiana Plescia ${ }^{\mathrm{a}}$, Stella Cascioferro ${ }^{\mathrm{a}}$, Salvatore Plescia ${ }^{\mathrm{a}}$, \\ Maria Valeria Raimondi ${ }^{a}$, Giuseppe Daidone ${ }^{\mathrm{a}}$, Manlio Tolomeo ${ }^{\mathrm{b}}$, Stefania Grimaudo ${ }^{\mathrm{b}}$, \\ Antonietta Di Cristina ${ }^{\mathrm{b}}$, Rosaria Maria Pipitone ${ }^{\mathrm{b}}$, Ruoli Bai ${ }^{\mathrm{c}}$, Ernest Hamel ${ }^{\mathrm{c}}$ \\ ${ }^{a}$ Dipartimento di Scienze e Tecnologie Molecolari e Biomolecolari, Via Archirafi, 32, 90123 Palermo, Italy \\ ${ }^{\mathrm{b}}$ Centro Interdipartimentale di Ricerca in Oncologia Clinica e Dipartimento Biomedico di Medicina Interna e Specialistica, Università di Palermo, Palermo, Italy \\ ' Screening Technologies Branch, Developmental Therapeutics Program, Division of Cancer Treatment and Diagnosis, National Cancer Institute at Frederick, \\ National Institutes of Health, Frederick, MD 21702, USA
}

\section{A R T I C L E I N F O}

\section{Article history:}

Received 29 September 2010

Received in revised form

23 March 2011

Accepted 31 March 2011

Available online 6 April 2011

Keywords:

2-\{[2E]-3-phenylprop-2-enoylamino $\}$

benzamides

Antimitotic agents

Cytotoxic activity

\begin{abstract}
A B S T R A C T
Several new 2-\{[(2E)-3-phenylprop-2-enoyl]amino\}benzamides $\mathbf{1 2 a}-\mathbf{s}$ and $\mathbf{1 7 t}-\mathbf{v}$ were synthesized by stirring in pyridine the (E)-3-(2-R1-3-R2-4-R3-phenyl)acrylic acid chlorides 11c-k and 11t-v with the appropriate anthranilamide derivatives $\mathbf{1 0} \mathbf{a}-\mathbf{c}$ or the 5-iodoanthranilic acid $\mathbf{1 3}$. Some of the synthesized compounds were evaluated for their in vitro antiproliferative activity against the full $\mathrm{NCI}$ tumor cell line panel derived from nine clinically isolated cancer types (leukemia, non-small cell lung, colon, CNS, melanoma, ovarian, renal, prostate and breast). COMPARE analysis, effects on tubulin polymerization in cells and with purified tubulin, and effects on cell cycle distribution for 17t, the most active of the series, indicate that these new antiproliferative compounds act as antitubulin agents.
\end{abstract}

(C) 2011 Elsevier Masson SAS. All rights reserved.

\section{Introduction}

During a screening program to find antiproliferative compounds in our laboratory's collection of small organic molecules, the 2-cinnamamido-5-iodobenzamide $\mathbf{1}$ was found at $10 \mu \mathrm{M}$ to inhibit proliferation of the leukemic cell line $\mathrm{K} 562$ by $74 \%$.

Compound 1 belongs to cinnamoyl anthranilates, which represent a class of biologically active substances of great importance in medicinal chemistry. Tranilast (Rizaben ${ }^{\circledR}$ ) $\mathbf{2}$ is an antiallergic drug approved in 1982 for use in Japan and South Korea for bronchial asthma and was also investigated for use as an antiproliferative agent on drug-eluting stents. Its derivative (E)-2-(3-(3,4-dimethoxyphenyl)acrylamido)benzamide 3 [1] is another member of this class of compounds and is more potent than the lead compound, Tranilast (Fig. 1).

Other biological activities possessed by this class of compounds are antifibrotic and antinflammatory properties [2,3] and inhibition of cornea pterygium progression and blood vessel development $[4,5]$. Finally, cinnamoyl anthranilates are useful for prevention and

\footnotetext{
* Corresponding author. Tel.: +39 9123891917.

E-mail address: demraffa@unipa.it (D. Raffa).
}

treatment of glomerular diseases [6] and diseases caused by the excessive proliferation of vascular intimal cells [7].

However, despite their wide range of biological activities, a review of the literature revealed that no anticancer activity had been described for cinnamoyl anthranilates. Thus, the activity of compound $\mathbf{1}$ as an inhibitor of K562 proliferation led us to explore the potential of this class of compounds as anticancer agents, and we therefore synthesized a series of novel cinnamoyl anthranilates and screened the compounds for antileukemic activity. Our work enabled us to perform an initial study of their structure-activity relationships and to determine their mechanism of action. Compounds $12 \mathbf{a}-\mathbf{s}$ and $\mathbf{1 7} \mathbf{t}-\mathbf{v}$ were initially tested in vitro for their antileukemic activity against the K562 (human chronic myelogenous leukemia) cell line (Table 1). Among these, 12a-c and $\mathbf{1 7 t}, \mathbf{u}$, which showed the best antiproliferative activity, were selected by the National Cancer Institute (NCI) for evaluation in the 60 human tumor cell line screen of the $\mathrm{NCI}$.

\section{Results and discussion}

\subsection{Chemistry}

A series of 2-\{[(2E)-3-phenylprop-2-enoyl ]amino\}benzamides 12a $-\mathbf{s}$ and $\mathbf{1 7 t}-\mathbf{v}$ was synthesized by stirring the $(E)-3-(2-\mathrm{R} 1-3-\mathrm{R} 2-$ 
<smiles>COc1ccc(/C=C/C(=O)Nc2ccccc2C(=O)O)cc1OC</smiles><smiles>COc1ccc(/C=C/C(=O)Nc2ccccc2C(N)=O)cc1OC</smiles>

Fig. 1. Structure of cinnamoyl anthranilates.

4-R3-phenyl)acrylic acid chlorides $11 \mathbf{c}-\mathbf{k}, \mathbf{1 1 t}-\mathbf{v}$ and the appropriate anthranilamide derivatives $\mathbf{1 0 a}-\mathbf{c}$ or the 5-iodoanthranilic acid $\mathbf{1 3}$ as described in Schemes 1 and 2.

Crude (E)-3-(2-R1-3-R2-4-R3-phenyl)acrylic acids 11c-k, 11t-v were obtained by refluxing the appropriately substituted acrylic acid $\mathbf{8 c}-\mathbf{k}, \mathbf{8 t}-\mathbf{v}$ with thionyl chloride. The 5-methylanthranilamide 10a was obtained by reduction of 2-nitro-5-methylbenzamideamide $\mathbf{7 a}$ as shown in Scheme 1. Compound $\mathbf{7}$ was obtained by reaction of the acid $\mathbf{5}$ with thionyl chloride to afford $\mathbf{6}$, followed by treatment of $\mathbf{6}$ with aqueous ammonia.

The anthranilamide derivatives $\mathbf{1 0 b}, \mathbf{c}$ were obtained by stirring the appropriate $2 H$-3,1-benzoxazine-2,4(1H)-dione $\mathbf{9 b , c}$ in aqueous ammonia solution (Scheme 1) [8].

A different synthetic method was used to obtain the 2-\{[(2E)-3phenylprop-2-enoyl]amino\}benzamides $\mathbf{1 7 t}-\mathbf{v}$ (Scheme 2). The

Table 1

Percent growth inhibition obtained with the K562 cell line with compounds at $10 \mu \mathrm{M}$ and $\mathrm{IC}_{50}$ values $(\mu \mathrm{M})$ with the same cells.

\begin{tabular}{llc}
\hline Com. & \% inhibition & IC50 $(\mu \mathrm{M})$ \\
\hline $\mathbf{4}$ & 14.2 & $>10$ \\
$\mathbf{1 2 a}$ & 65.4 & 5.5 \\
$\mathbf{1 2 b}$ & 64.0 & 2.5 \\
$\mathbf{1 2 c}$ & 62.4 & 5.0 \\
$\mathbf{1 2 d}$ & 58.0 & 7.4 \\
$\mathbf{1 2}$ & 28.2 & $>10$ \\
$\mathbf{1 2 f}$ & 31.0 & $>10$ \\
$\mathbf{1 2 g}$ & 49.0 & 10 \\
$\mathbf{1 2 h}$ & 27.0 & $>10$ \\
$\mathbf{1 2 i}$ & 52.2 & 9.5 \\
$\mathbf{1 2 j}$ & 37.8 & $>10$ \\
$\mathbf{1 2}$ & 64.0 & 6.3 \\
$\mathbf{1 2 1}$ & 59.0 & 8.1 \\
$\mathbf{1 2 m}$ & 25.5 & $>10$ \\
$\mathbf{1 2 n}$ & 22.0 & $>10$ \\
$\mathbf{1 2 0}$ & 46.2 & $>10$ \\
$\mathbf{1 2}$ & 45.9 & $>10$ \\
$\mathbf{1 2 q}$ & 43.2 & $>10$ \\
$\mathbf{1 2}$ & 43.8 & $>10$ \\
$\mathbf{1 2 s}$ & 45.9 & $>10$ \\
$\mathbf{1 7 t}$ & 74.5 & 0.57 \\
$\mathbf{1 7}$ & 74.1 & 1.2 \\
$\mathbf{1 7}$ & 26.3 & $>10$ \\
$\mathbf{1 8}$ & 63.6 & 0.02 \\
\hline
\end{tabular}

starting materials, 2-cinnamamido-5-iodobenzoic acids $\mathbf{1 5 t}-\mathbf{v}$, were obtained by stirring the 5-iodoanthranilic acid 13 and the cinnamoyl chlorides 11t $-\mathbf{v}$. The reaction gave a mixture of $(E)-6$ iodo-2-styryl-4H-benzo[d] [1,3]oxazin-4-ones $\mathbf{1 4 t}-\mathbf{u}$ and 2-cinnamamido-5-iodobenzoic acids $\mathbf{1 5 t}-\mathbf{u}$, and the mixtures were treated with aqueous $\mathrm{Na}_{3} \mathrm{PO}_{4}$ [9] to give the corresponding acids 15t [10], $\mathbf{1 5 u}, \mathbf{v}$ as the only products. By treating the acids $\mathbf{1 5 t}-\mathbf{v}$ with ethyl chloroformate, the $2 H$-3,1-benzoxazine-2,4-diones $\mathbf{1 6 t}-\mathbf{v}$ were obtained [11], which, in turn, converted to the 2-\{[2E]-3-phenylprop-2-enoylamino\}benzamides $\mathbf{1 7 t}-\mathbf{v}$ by refluxing them in an aqueous ammonia solution [8].

The structures of the new compounds were determined by analytical and spectroscopic measurements. In particular, ${ }^{1} \mathrm{H}$ NMR spectra of compounds $12 \mathbf{a}-\mathbf{s}$ and $17 \mathbf{v}-\mathbf{t}$ were consistent with an E-olefinic structure. They showed signals attributable to the $\beta$-olefinic protons at $6.66-6.97 \delta$ with coupling constants of $16.6-14.7 \mathrm{~Hz}$, as required for $E$-structures [12], while the $\alpha$-olefinic hydrogens were found along with aromatic multiplets. Moreover, their ${ }^{1} \mathrm{H}$ NMR spectra showed both the $\mathrm{NH}$ and $\mathrm{NH}_{2}$ amidic signals; the cinnamamido $\mathrm{NH}$ proton appeared as a singlet at 11.77-11.92 $\delta$, while, according to the literature [13], the presence of an intramolecular hydrogen bond renders the benzamido $\mathrm{NH}_{2}$ protons diastereotopic. $\mathrm{H}_{\mathrm{a}}$ is easily exchangeable with $\mathrm{D}_{2} \mathrm{O}$ and appeared as a singlet at $8.24-8.44 \delta . \mathrm{H}_{\mathrm{b}}$ was found at a lower field along with the aromatic multiplets.

\subsection{Biology}

Synthesized 2-\{[(2E)-3-phenylprop-2-enoyl]amino\}benzamides $12 \mathbf{a}-\mathbf{s}$ and $\mathbf{1 7 t}-\mathbf{v}$ were initially tested in vitro for their antileukemic activity against the K562 (human chronic myelogenous leukemia) cell line. Colchicine 18, whose antileukemic activity is well known, and the 2-cinnamamidobenzamide 4 [13] (Fig. 1), were used as reference compounds. The percent growth inhibition at a screening concentration of $10 \mu \mathrm{M}$ and the IC $_{50}$ values for compounds that exhibited at least $50 \%$ of growth inhibition at $10 \mu \mathrm{M}$ are shown in Table 1 . Compounds $12 \mathbf{a}-\mathbf{s}$ and $\mathbf{1 7 t}-\mathbf{v}$ had inhibitory activity against the K562 cells ranging from 22.0 to $74.5 \%$ at $10 \mu \mathrm{M}$, with $\mathbf{1 2 a}-\mathbf{d}, \mathbf{1 2 k}, \mathbf{1}$, and $\mathbf{1 7 t}, \mathbf{u}\left(\mathrm{IC}_{50} 0.57-8.1 \mu \mathrm{M}\right)$ being the most active compounds. Our data (Table 1 ) showed positive effects following substitution with halogens at the 5 position of the benzamido moiety, especially when the substituent was iodine (compounds $\mathbf{1 7 t}$ and $\mathbf{1 7} \mathbf{u}$ ). As far as structure-activity relationships are concerned, it seems that the introduction of a substituent in both the benzamido and styryl moieties are favorable for inhibition of $\mathrm{K} 562$ cell growth relative to the unsubstituted 2-cinnamamidobenzamide 4 (Table 1 ). However, the best activity was obtained when the substitutions were present only on the benzamido moiety (compounds 12a-d, 17t). Compounds substituted in both the benzamido and styryl moieties (compounds $12 \mathbf{e}-\mathbf{s}, \mathbf{1 7} \mathbf{v}$ ) were less active, even if antiproliferative activity was maintained in the ortho-styryl derivatives (12d,i,l,u).

Compounds 12a, 12b, 12c, $17 t$ and $17 \mathbf{u}$ were evaluated by the $\mathrm{NCI}$ for testing against a panel of approximately 60 human cell lines derived from seven clinically isolated cancer types (lung, colon, melanoma, renal, ovarian, brain, and leukemia) according to the NCI standard protocol [14] (Table 2). The data summarized in Table 2 showed that $\mathbf{1 2 a}, \mathbf{1 2 b}, \mathbf{1 2 c}, \mathbf{1 7 t}$ and $\mathbf{1 7} \mathbf{u}$ caused $50 \%$ growth inhibition at micromolar (12a, 12b, 12c) and submicromolar concentrations $(\mathbf{1 7 t}, \mathbf{1 7} \mathbf{u})$ against every type of tumor cell line investigated.

Moreover, a mean graph midpoint (MG_MID) is calculated for the GI50, TGI and LC50 parameters, giving an average activity parameter for all the cell lines. For the calculation of the MG_MID, insensitive cell lines are included and assigned as their values the highest concentration tested. Considering the MG_MID values 
<smiles>Cc1ccc([N+](=O)[O-])c(C(=O)O)c1</smiles><smiles>CCCCC</smiles>
5

$\begin{array}{ll}\mathbf{8 c} & \mathrm{R}_{1}=\mathrm{H}, \mathrm{R}_{2}=\mathrm{H}, \mathrm{R}_{3}=\mathrm{H} \\ \mathbf{8 d} & \mathrm{R}_{1}=\mathrm{Cl}, \mathrm{R}_{2}=\mathrm{H}, \mathrm{R}_{3}=\mathrm{H} \\ \mathbf{8 e} & \mathrm{R}_{1}=\mathrm{H}, \mathrm{R}_{2}=\mathrm{Cl}, \mathrm{R}_{3}=\mathrm{H} \\ \mathbf{8 f} & \mathrm{R}_{1}=\mathrm{H}, \mathrm{R}_{2}=\mathrm{H}, \mathrm{R}_{3}=\mathrm{Cl} \\ \mathbf{8 g} & \mathrm{R}_{1}=\mathrm{Br}, \mathrm{R}_{2}=\mathrm{H}, \mathrm{R}_{3}=\mathrm{H} \\ \mathbf{8 h} & \mathrm{R}_{1}=\mathrm{H}, \mathrm{R}_{2}=\mathrm{Br}, \mathrm{R}_{3}=\mathrm{H} \\ \mathbf{8 i} & \mathrm{R}_{1}=\mathrm{CH}_{3}, \mathrm{R}_{2}=\mathrm{H}, \mathrm{R}_{3}=\mathrm{H} \\ \mathbf{8 j} & \mathrm{R}_{1}=\mathrm{H}, \mathrm{R}_{2}=\mathrm{CH}_{3}, \mathrm{R}_{3}=\mathrm{H} \\ \mathbf{8 k} & \mathrm{R}_{1}=\mathrm{H}, \mathrm{R}_{2}=\mathrm{H}, \mathrm{R}_{3}=\mathrm{CH} \mathrm{H}_{3} \\ \mathbf{9 b} & \mathrm{R}=\mathrm{Cl} \\ \mathbf{9 c} & \mathrm{R}=\mathrm{Br} \\ \mathbf{1 0 a} & \mathrm{R}=\mathrm{CH} \\ \mathbf{1 0 b} & \mathrm{R}=\mathrm{Cl} \\ \mathbf{1 0 c} & \mathrm{R}=\mathrm{Br} \\ \mathbf{1 1 c} & \mathrm{R}_{1}=\mathrm{H}, \mathrm{R}_{2}=\mathrm{H}, \mathrm{R}_{3}=\mathrm{H} \\ \mathbf{1 1 d} & \mathrm{R}_{1}=\mathrm{Cl}, \mathrm{R}_{2}=\mathrm{H}, \mathrm{R}_{3}=\mathrm{H} \\ \mathbf{1 1 e} & \mathrm{R}_{1}=\mathrm{H}, \mathrm{R}_{2}=\mathrm{Cl}, \mathrm{R}_{3}=\mathrm{H} \\ \mathbf{1 1 f} & \mathrm{R}_{1}=\mathrm{H}, \mathrm{R}_{2}=\mathrm{H}, \mathrm{R}_{3}=\mathrm{Cl} \\ \mathbf{1 1 g} & \mathrm{R}_{1}=\mathrm{Br}_{2} \mathrm{R}_{2}=\mathrm{H}, \mathrm{R}_{3}=\mathrm{H} \\ \mathbf{1 1 h} & \mathrm{R}_{1}=\mathrm{H}, \mathrm{R}_{2}=\mathrm{Br}, \mathrm{R}_{3}=\mathrm{H} \\ \mathbf{1 1 i} & \mathrm{R}_{1}=\mathrm{CH}_{3}, \mathrm{R}_{2}=\mathrm{H}, \mathrm{R}_{3}=\mathrm{H}\end{array}$<smiles>Cc1ccc([N+](=O)[O-])c(C(=O)Cl)c1</smiles><smiles>C1CCCCC1</smiles>
6 b $\mathrm{H}_{3}$<smiles>Cc1ccc([N+](=O)[O-])c(C(N)=O)c1</smiles>
7<smiles>[3H][CH]</smiles><smiles>[R]c1ccc2[nH]c(=O)oc(=O)c2c1</smiles><smiles>CCCC</smiles>

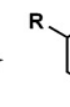<smiles>Cc1ccc(N)c(C(N)=O)c1</smiles>

10a-c<smiles>[R]c1ccc(/C=C/C(=O)O)c([R])c1[R]</smiles>

8c-k a<smiles>[R3]c1ccc(/C=C/C(=O)Cl)c([R])c1[R]</smiles>

$$
\begin{aligned}
& 11 \mathbf{k} \mathrm{R}_{1}=\mathrm{H}, \mathrm{R}_{2}=\mathrm{H}, \mathrm{R}_{3}=\mathrm{CH}_{3} \\
& \text { 12a } \mathrm{R}=\mathrm{CH}_{3}, \mathrm{R} 1=\mathrm{H}, \mathrm{R}_{2}=\mathrm{H}, \mathrm{R}_{3}=\mathrm{H} \\
& \text { 12b } \mathrm{R}=\mathrm{Cl}, \mathrm{R}_{1}=\mathrm{H}, \mathrm{R}_{2}=\mathrm{H}, \mathrm{R}_{3}=\mathrm{H} \\
& 12 \mathrm{c} \quad \mathrm{R}=\mathrm{Br}, \mathrm{R}_{1}=\mathrm{H}, \mathrm{R}_{2}=\mathrm{H}, \mathrm{R}_{3}=\mathrm{H} \\
& 12 d \quad \mathrm{R}=\mathrm{Cl}, \mathrm{R}_{1}=\mathrm{Cl}, \mathrm{R}_{2}=\mathrm{H}, \mathrm{R}_{3}=\mathrm{H} \\
& \text { 12e } \mathrm{R}=\mathrm{Cl}, \mathrm{R}_{1}=\mathrm{H}, \mathrm{R}_{2}=\mathrm{Cl}, \mathrm{R}_{3}=\mathrm{H} \\
& 12 \mathrm{f} \quad \mathrm{R}=\mathrm{Cl}, \mathrm{R}_{1}=\mathrm{H}, \mathrm{R}_{2}=\mathrm{H}, \mathrm{R}_{3}=\mathrm{Cl} \\
& 12 \mathrm{~g} \quad \mathrm{R}=\mathrm{Cl}, \mathrm{R}_{1}=\mathrm{Br}, \mathrm{R}_{2}=\mathrm{H}, \mathrm{R}_{3}=\mathrm{H} \\
& 12 \mathrm{~h} R=\mathrm{Cl}, \mathrm{R}_{1}=\mathrm{H}, \mathrm{R}_{2}=\mathrm{Br}, \mathrm{R}_{3}=\mathrm{H} \\
& 12 \mathrm{i} \quad \mathrm{R}=\mathrm{Cl}, \mathrm{R}_{1}=\mathrm{CH}_{3}, \mathrm{R}_{2}=\mathrm{H}, \mathrm{R}_{3}=\mathrm{H} \\
& \text { 12j } \mathrm{R}=\mathrm{Cl}, \mathrm{R}_{1}=\mathrm{H}, \mathrm{R}_{2}=\mathrm{CH}_{3}, \mathrm{R}_{3}=\mathrm{H} \\
& 12 \mathbf{k} \mathrm{R}=\mathrm{Cl}, \mathrm{R}_{1}=\mathrm{H}, \mathrm{R}_{2}=\mathrm{H}, \mathrm{R}_{3}=\mathrm{CH}_{3} \\
& 12 \mathrm{R}=\mathrm{Br}, \mathrm{R}_{1}=\mathrm{Cl}, \mathrm{R}_{2}=\mathrm{H}, \mathrm{R}_{3}=\mathrm{H} \\
& 12 \mathrm{~m} \quad \mathrm{R}=\mathrm{Br}, \mathrm{R}_{1}=\mathrm{H}, \mathrm{R}_{2}=\mathrm{Cl}, \mathrm{R}_{3}=\mathrm{H} \\
& 12 n \quad \mathrm{R}=\mathrm{Br}, \mathrm{R}_{1}=\mathrm{H}, \mathrm{R}_{2}=\mathrm{H}, \mathrm{R}_{3}=\mathrm{Cl} \\
& 1^{\circ} \quad \mathrm{R}=\mathrm{Br}, \mathrm{R}_{1}=\mathrm{Br}, \mathrm{R}_{2}=\mathrm{H}, \mathrm{R}_{3}=\mathrm{H} \\
& 12 \mathrm{p} R=\mathrm{Br}, \mathrm{R}_{1}=\mathrm{H}, \mathrm{R}_{2}=\mathrm{Br}, \mathrm{R}_{3}=\mathrm{H} \\
& 12 \mathrm{q} R=\mathrm{Br}, \mathrm{R}_{1}=\mathrm{CH}_{3}, \mathrm{R}_{2}=\mathrm{H}, \mathrm{R}_{3}=\mathrm{H} \\
& 12 \mathrm{r} \quad \mathrm{R}=\mathrm{Br}, \mathrm{R}_{1}=\mathrm{H}, \mathrm{R}_{2}=\mathrm{CH}_{3}, \mathrm{R}_{3}=\mathrm{H} \\
& \text { 12s } \mathrm{R}=\mathrm{Br}, \mathrm{R}_{1}=\mathrm{H}, \mathrm{R}_{2}=\mathrm{H}, \mathrm{R}_{3}=\mathrm{CH}_{3}
\end{aligned}
$$$$
11 \mathrm{j} \quad \mathrm{R}_{1}=\mathrm{H}, \mathrm{R}_{2}=\mathrm{CH}_{3}, \mathrm{R}_{3}=\mathrm{H}
$$

Scheme 1. Reagents and conditions: (a) $\mathrm{SOCl}_{2}$, reflux, $5 \mathrm{~h}$; (b) acetonitrile, aqueous ammonia (25\%), reflux, $8 \mathrm{~h}$; (c) aqueous ammonia (25\%), stirring, rt, 1 h; (d) $\mathrm{SnCl}$, $\mathrm{HCl}(35 \%)$, stirring, $0-5{ }^{\circ} \mathrm{C},(24 \mathrm{~h}) ;(\mathrm{e})$ pyridine, stirring, rt, $24 \mathrm{~h}$.

(Table 3), the most active compound of the series was derivative $\mathbf{1 7 t}$, at both the GI50 and TGI levels, followed by $\mathbf{1 7} \mathbf{u}$ and $\mathbf{1 2 c}$.

Compound 17t was selected by the $\mathrm{NCI}$ for evaluation in its vivo toxicity assay, with the finding that the compound was nontoxic at a dose of $400 \mathrm{mg} / \mathrm{kg}$ in nontumored mice. Compound 17t was also selected by the NCI for testing in the hollow fiber assay, a preliminary in vivo screening tool, but the compound was not sufficiently active for evaluation in xenograft models.

To predict the probable mechanism of action, the NCl's bioinformatic tool COMPARE analysis [15] was performed for the most active compound 17t. When tested as seed against the NCI "standard agents" Database, the compound showed Pearson Correlation Coefficients (PCC) of 0.492 and 0.476 at the GI50 level and higher values, $0.677,0.600,0.597$, at the TGI level. In all cases the highest PCC's were with compounds NSC 332598 (rhizoxin), NSC 125973 (paclitaxel), NSC 49842 (vinblastine sulfate) and NSC 153858 (maytansine), which are all antimitotic agents directed against tubulin.

To verify the prediction of the COMPARE algorithm, the effects of 17t on cell cycle distribution as determined by flow cytometry and on tubulin polymerization were evaluated.

As shown in Fig. 2, 17t caused a dose dependant increase of K562 cells in the G2-M phase of the cell cycle and a decrease of cells in G0-G1 after a $24 \mathrm{~h}$ treatment. This is the typical flow cytometric cell cycle distribution observed with drugs targeting tubulin (see panel b in Fig. 2), which is the main component of the mitotic spindle.

After $48 \mathrm{~h} \mathbf{1 7 t}$ caused extensive apoptosis in K562 cells, with an AC50 (concentration inducing 50\% apoptosis) of $3.7 \mu \mathrm{M}$ (Fig. 3). Apoptosis in this experiment was measured as described in the Experimental Section.
To confirm the ability of $\mathbf{1 7 t}$ to act on microtubules, the percentage of cells blocked in mitosis (M) was morphologically determined after staining cells with ethidium bromide and acridine orange. The percentage of $\mathrm{K} 562$ cells blocked in the M phase after $24 \mathrm{~h}$ of exposure to $1 \mu \mathrm{M} 17 \mathrm{t}$ was $35 \pm 6$ (Fig. $4 \mathrm{~A}$, untreated $\mathrm{K} 562$ cell as control $<1 \%$ ). Of interest, concentrations of 17t higher than $2 \mu \mathrm{M}$ induced morphologic alterations in almost all treated cells, suggesting an interaction between $\mathbf{1 7 t}$ and the cytoskeleton of K562 cells (Fig. 4C and D).

To examine the effects of $\mathbf{1 7 t}$ on microtubules (tubulin) and microfilaments (actin), PtK2 cells were examined by direct immunofluorescence. These cells were selected for this examination since their flattened morphology yields high quality images of cytoskeletal elements, particularly the microtubule and microfilament networks. As shown in Fig. 5, the microtubules disappeared while the microfilaments persisted with micromolar 17t. In addition, we found that $\mathbf{1 7 t}$ partially inhibited the polymerization of purified tubulin, but this effect was relatively weak, as shown in Fig. 6, with a comparison to the much stronger inhibition observed with colchicine 18. With 17t, we observed a concentration dependent inhibition of the rate of microtubule assembly, beginning at about $10 \mu \mathrm{M}$. However, within the concentration range we were able to examine (up to $40 \mu \mathrm{M}$ ), there was no effect on the extent of assembly. It should be pointed out that $\mathbf{1 7 t}$ appeared to partially precipitate at $40 \mu \mathrm{M}$. With the classic antitubulin agent colchicine 18 , the rate of assembly was $50 \%$ inhibited at about $2 \mu \mathrm{M}$, and the extent of assembly at about $5 \mu \mathrm{M}$. At 7 and $10 \mu \mathrm{M}$ colchicine $\mathbf{1 8}$, tubulin polymerization was essentially completely inhibited, an effect that we were unable to achieve with 17t.

Taken together, our data suggest that $\mathbf{1 7 t}$ interacts with tubulin, preventing formation of the mitotic spindle and thereby caused 
<smiles>[R3]c1ccc(/C=C/C(=O)O)c([R])c1/C=C/c1nc2ccc(I)cc2c(=O)o1</smiles>

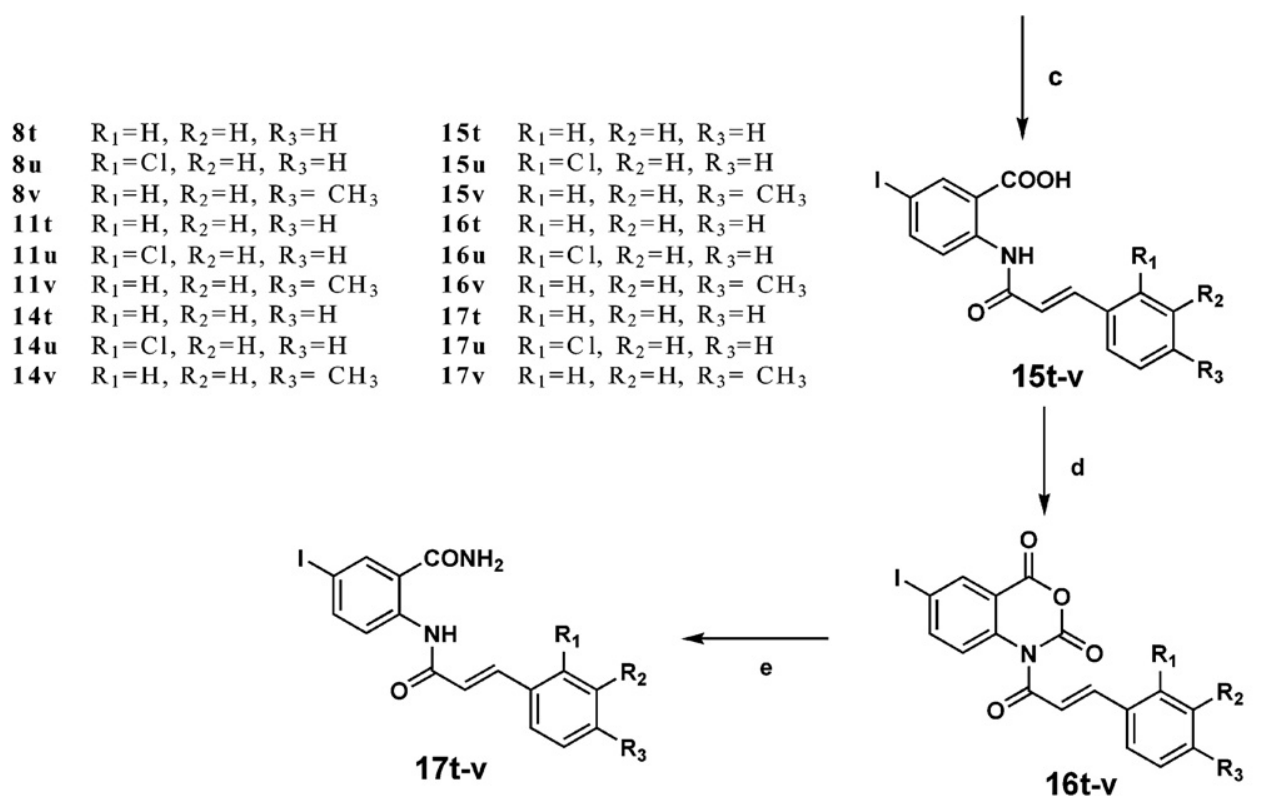

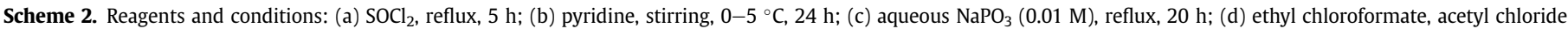
reflux, (15 min + $30 \mathrm{~min}$ ); (e) dioxane, acqueous ammonia (25\%), reflux, $3 \mathrm{~h}$.

the block in $\mathrm{M}$ phase. Inhibition of tubulin assembly would also disrupt the integrity of the microtubule cytoskeleton in interphase cells, causing extensive alterations in cell morphology. Although its effect on in vitro tubulin assembly is relatively weak, the cellular effects obtained with $\mathbf{1 7 t}$ are most consistent with those observed with more potent antitubulin agents. Furthermore, disruption of cellular microtubules invariably results in activation of cellular apoptosis.

\section{Conclusions}

The data reported here show that the 2-\{[2E]-3-phenylprop2-enoylamino benzamides $\mathbf{1 2 a}-\mathbf{s}$ and $\mathbf{1 7 t}-\mathbf{v}$ caused growth inhibition against many tumor cell lines. The best agents inhibited proliferation at low micromolar $(\mathbf{1 2 a}, \mathbf{1 2 b}, \mathbf{1 2 c})$ and submicromolar concentrations $(\mathbf{1 7 t}, \mathbf{1 7} \mathbf{u})$ against every tumor cell line investigated. The best activity was obtained when the 5 position of the benzamido moiety was substituted with an iodine atom. COMPARE analysis, effects on tubulin polymerization in cells and with purified tubulin, and effects on cell cycle distribution, including induction of apoptosis, indicate that these new antiproliferative compounds act as antitubulin agents.

\section{Experimental}

\subsection{Chemistry}

\subsubsection{General}

Reaction progress was monitored by TLC on silica gel plates (Merck 60, $\mathrm{F}_{254}, 0.2 \mathrm{~mm}$ ). Organic solutions were dried over $\mathrm{Na}_{2} \mathrm{SO}_{4}$. Evaporation refers to the removal of solvent on a rotary evaporator under reduced pressure. All melting points were determined on a Büchi 530 capillary melting point apparatus and are uncorrected. IR spectra were recorded with a Perkin Elmer Spectrum RXI FT-IR System spectrophotometer, with compound as a solid in a $\mathrm{KBr}$ disc. ${ }^{1} \mathrm{H}$ NMR spectra were obtained using a Bruker AC-E $300 \mathrm{MHz}$ spectrometer (tetramethylsilane as internal standard): chemical shifts are expressed in $\delta$ values (ppm). Merck silica gel (Kiesegel 60/230-400 mesh) was used for flash chromatography columns. Microanalyses data $(\mathrm{C}, \mathrm{H}, \mathrm{N})$ were obtained by an Elemental Vario EL III apparatus and were within $\pm 0.4 \%$ of the theoretical values. Yields refer to purified products and are not optimized. The names of the products were obtained using the ACD/I-Lab Web service (ACD/IUPAC Name Free 8.05). 
Table 2

Results of multi-dose growth inhibition assay (GI50, $\mu \mathrm{M})$.

\begin{tabular}{|c|c|c|c|c|c|c|}
\hline Cell line & & $12 a$ & 12b & $12 c$ & $17 t$ & $17 u$ \\
\hline \multirow[t]{5}{*}{ Leukemia } & CCRF-CEM & 2.36 & 2.96 & 0.429 & 0.341 & 0.484 \\
\hline & HL-60 (TB) & 1.77 & 1.42 & 0.346 & 0.0542 & 0.165 \\
\hline & $\mathrm{K}-562$ & 1.11 & 0.845 & 0.415 & 0.920 & 0.370 \\
\hline & MOLT-4 & 3.56 & 3.95 & 1.86 & 0.202 & 1.42 \\
\hline & RPMI-8226 & nt & 2.79 & 1.03 & 0.347 & 0.772 \\
\hline Non-small cell & A549/ATCC & 5.81 & 3.77 & 1.02 & 2.65 & 1.87 \\
\hline \multirow[t]{7}{*}{ lung cancer } & EKVX & 5.18 & 2.83 & 2.41 & 0.734 & 1.00 \\
\hline & HOP-62 & 7.74 & 3.15 & 1.51 & 0.800 & 2.30 \\
\hline & HOP-92 & 11.4 & 2.87 & 1.96 & 21.2 & 13.2 \\
\hline & $\mathrm{NCI}-\mathrm{H} 226$ & 7.28 & 3.00 & 2.61 & 1.09 & 1.14 \\
\hline & $\mathrm{NCI}-\mathrm{H} 23$ & 3.38 & 3.37 & 1.09 & 0.840 & 1.39 \\
\hline & $\mathrm{NCI}-\mathrm{H} 460$ & 3.59 & 1.76 & 0.662 & 0.453 & 0.479 \\
\hline & $\mathrm{NCI}-\mathrm{H} 522$ & 2.83 & 2.08 & nt & 0.303 & 0.459 \\
\hline \multirow[t]{7}{*}{ Colon cancer } & COLO 205 & 1.84 & 1.68 & 0.917 & 0.343 & 0.797 \\
\hline & HCC-2998 & 6.45 & 0.487 & nt & 1.25 & 0.984 \\
\hline & НСТ-116 & 3.20 & 1.98 & 0.663 & 0.430 & 0.509 \\
\hline & HCT-15 & 3.77 & 2.13 & 1.04 & 0.586 & 0.987 \\
\hline & HТ29 & 2.31 & 1.94 & 0.527 & 0.367 & 0.376 \\
\hline & KM12 & 2.94 & 1.69 & 0.739 & 0.499 & 0.533 \\
\hline & SW-620 & 3.30 & 1.99 & 0.705 & 0.541 & 0.605 \\
\hline \multirow[t]{6}{*}{ CNS cancer } & SF-268 & 10.9 & 2.90 & 1.83 & 2.31 & 0.778 \\
\hline & SF-295 & 3.14 & 1.40 & 0.625 & 0.350 & 0.415 \\
\hline & SF539 & 2.05 & 2.05 & 0.819 & 0.445 & 0.444 \\
\hline & SNB-19 & 5.69 & 3.18 & 2.00 & 0.586 & 1.41 \\
\hline & SNB75 & 3.18 & 1.84 & 2.07 & 0.245 & 1.22 \\
\hline & U251 & 4.13 & 2.14 & 0.887 & 0.501 & 0.663 \\
\hline \multirow[t]{9}{*}{ Melanoma } & LOX IMVI & 7.65 & 4.33 & 3.27 & 3.75 & 4.21 \\
\hline & MALME-3M & 7.59 & 2.68 & 1.21 & 1.60 & $\mathrm{nt}$ \\
\hline & M14 & 2.35 & 1.71 & 0.482 & 0.429 & 0.698 \\
\hline & MDA-MB-435 & 0.660 & 0.492 & 0.231 & nt & 0.234 \\
\hline & SK-MEL-2 & 4.75 & 2.75 & nt & 1.40 & 0.678 \\
\hline & SK-MEL-28 & 5.24 & 2.88 & 0.839 & 2.51 & nt \\
\hline & SK-MEL-5 & 1.01 & 0.373 & 0.435 & 0.383 & 0.367 \\
\hline & UACC-257 & 17.0 & 15.1 & nt & 14.3 & 38.7 \\
\hline & UACC-62 & 3.77 & 2.52 & 0.782 & 0.632 & 0.388 \\
\hline \multirow[t]{7}{*}{ Ovarian cancer } & IGROV1 & 4.37 & 3.29 & 1023 & 0.917 & 0.352 \\
\hline & OVCAR-3 & 2.18 & 1.30 & 0.349 & 0.353 & 0.294 \\
\hline & OVCAR-4 & 11.4 & 2.77 & nt & 1.84 & 2.37 \\
\hline & OVCAR-5 & 8.20 & 2.74 & 2.92 & 3.52 & 4.02 \\
\hline & OVCAR-8 & 7.49 & 3.89 & nt & 1.06 & 56.0 \\
\hline & NCI/ADR-RES & 2.79 & 2.24 & 0.400 & nt & 0.719 \\
\hline & SK-OV-3 & 2.79 & 2.30 & 1.41 & 0.744 & 0.539 \\
\hline \multirow[t]{8}{*}{ Renal cancer } & $786-0$ & 4.00 & 2.32 & 1.76 & 1.43 & 0.937 \\
\hline & A498 & 5.56 & 3.61 & 1.70 & 2.70 & 0.880 \\
\hline & ACHN & 13.5 & 4.75 & 3.36 & 3.70 & 9.86 \\
\hline & CAKI-1 & 8.92 & 0.263 & 1.34 & 0.648 & 0.637 \\
\hline & RXF 393 & nt & 1.71 & 0.444 & 3.02 & 0.425 \\
\hline & SN12C & 9.63 & 3.96 & 2.96 & 0.635 & 1.55 \\
\hline & TK-10 & 25.8 & 5.51 & 2.67 & 3.15 & 26.7 \\
\hline & UO-31 & 9.62 & 3.57 & 1.85 & 3.53 & 1.63 \\
\hline \multirow[t]{2}{*}{ Prostate cancer } & PC-3 & 3.97 & 3.15 & 0.684 & 0.628 & 0.832 \\
\hline & DU-145 & 3.66 & 2.16 & 0.935 & 0.477 & 1.28 \\
\hline \multirow[t]{6}{*}{ Breast cancer } & MCF7 & 3.48 & 1.74 & 0.569 & 0.450 & 0.401 \\
\hline & MDA-MB-231 & 7.26 & 2.48 & 2.19 & 0.596 & 1.41 \\
\hline & HS 578T & 1.94 & 2.04 & 0.624 & 0.375 & 0.362 \\
\hline & BT-549 & 4.88 & 3.19 & 1.41 & 9.47 & 0.816 \\
\hline & $\mathrm{T}-47 \mathrm{D}$ & 4.20 & 3.36 & 1.57 & 0.857 & 19.9 \\
\hline & MDA-MB-468 & 3.12 & 1.17 & 0.279 & nt & 0.377 \\
\hline
\end{tabular}

nt $=$ not tested.

GI50 = Growth inhibition of 50\%; $[(\mathrm{Ti}-\mathrm{Tz}) /(\mathrm{C}-\mathrm{Tz})] \times 100=50$ where $\mathrm{Tz}=$ absorbance at $t=0, \mathrm{Ti}=$ absorbance at $t=48 \mathrm{~h}, \mathrm{C}=$ absorbance of control at $t=48 \mathrm{~h}$.

4.1.2. General procedure for preparation of 5-methyl-2nitrobenzoyl chloride $\mathbf{6 a}$ and 3-phenylacryloyl chlorides 11c-k, $11 t-v$

Substituted benzoyl and acryloyl chlorides $6 \mathbf{a}, \mathbf{1 1 c}-\mathbf{k}$ and $11 \mathrm{t}-\mathbf{v}$ were obtained by refluxing for $5 \mathrm{~h}$ the appropriate acid derivatives 5a, 8c- $-\mathbf{k}$ and $\mathbf{8 t}-\mathbf{v}(0.01 \mathrm{~mol})$ with thionyl chloride (7.25 ml) [16]. After evaporation under reduced pressure, the crude liquid residue was used for subsequent reactions without purification.

\subsubsection{Preparation of 5-methyl-2-nitrobenzamide $\mathbf{7 a}$}

To $0.01 \mathrm{~mol}$ of 5-methyl-2-nitrobenzoyl chloride $\mathbf{6 a} 10 \mathrm{ml}$ of aqueous ammonia solution (25\%) and $33 \mathrm{ml}$ of acetonitrile were added. The solution was first refluxed for $8 \mathrm{~h}$, then evaporated under reduced pressure to give pure $\mathbf{7 a}$.

\subsubsection{Preparation of 5-methyl-2-aminobenzamide $\mathbf{1 0 a}$}

To a magnetically stirred suspension of stannous chloride $(0.038 \mathrm{~mol})$ in concentrated $\mathrm{HCl}(37 \%)(15 \mathrm{ml}), 0.013$ mole of $7 \mathbf{a}$ was added at a rate so that the temperature of the slurry was maintained below $5{ }^{\circ} \mathrm{C}$ (about $1 \mathrm{~h}$ ). After addition was complete, the mixture was stirred for $24 \mathrm{~h}$. The white slurry thus obtained was diluted with cold water $(150 \mathrm{ml})$, and aqueous sodium hydroxide (40\%) was added until the tin salt dissolved. The solution was extracted with ethyl acetate $(3 \times 150 \mathrm{ml})$, and the extracts dried and evaporated in vacuo to obtain pure 10a.

\subsubsection{General procedure for preparation of aminobenzamides $\mathbf{1 0 b , c}$}

A mixture of $0.01 \mathrm{~mol}$ of $2 \mathrm{H}$-3,1-benzoxazine-2,4(1H)-diones 9b,c and $25 \mathrm{ml}$ of aqueous ammonia solution (25\%) was stirred for $1 \mathrm{~h}$. The solid precipitate was removed by filtration, washed with an aqueous ammonia solution (5\%) and crystallized from ethanol.

\subsubsection{General procedure for preparation of 2-\{[(2E)-3-phenylprop-} 2-enoyl]amino\}benzamides $\mathbf{1 2 a}-\boldsymbol{s}$

To a cold $\left(0-5{ }^{\circ} \mathrm{C}\right)$ stirred suspension of aminobenzamides $\mathbf{1 0 a}-\mathbf{c}(0.016 \mathrm{~mol})$ in pyridine $(13 \mathrm{ml}), 0.016 \mathrm{~mol}$ of the appropriate 3-phenylacryloyl chloride 11c-k was added over $30 \mathrm{~min}$. After addition was complete, the solution was stirred for $24 \mathrm{~h}$ and then poured onto crushed ice. The precipitate was removed by filtration, washed with water, and crystallized from ethanol.

5-Methyl-2-\{[(2E)-3-phenylprop-2-enoyl $]$ amino $\}$ benzamide (12a): yield 85\%; mp 228-230 ${ }^{\circ} \mathrm{C}$ (dioxane); I.R. (KBr) $\mathrm{cm}^{-1} 3400-$ $3258\left(\mathrm{NH}, \mathrm{NH}_{2}\right), 1681,1651$ (2XCO); ${ }^{1} \mathrm{H}$ NMR (DMSO) $\delta 2.31(\mathrm{~s}, 3 \mathrm{H}$, $\left.\mathrm{CH}_{3}\right) ; 6.89(\mathrm{~d}, 1 \mathrm{H}, J=15.6 \mathrm{~Hz}$, olefinic $\mathrm{CH}$ ); 7.32-8.49 (a set of signals, $9 \mathrm{H}$, aromatic protons and $\mathrm{NH}-\mathrm{H}) ; 7.58(\mathrm{~d}, 1 \mathrm{H}, J=15.6 \mathrm{~Hz}$, olefinic $\mathrm{CH}) ; 8.24(\mathrm{~s}, 1 \mathrm{H}, \mathrm{NH}-\mathrm{H}$, exchangeable); $11.80(\mathrm{~s}, 1 \mathrm{H}, \mathrm{NH}$, exchangeable). Anal. $\left(\mathrm{C}_{17} \mathrm{H}_{16} \mathrm{~N}_{2} \overline{\mathrm{O}}_{2}\right) \mathrm{C}, \mathrm{H}, \mathrm{N}$

5-Chloro-2-\{[(2E)-3-phenylprop-2-enoyl Jamino\}benzamides (12b): yield 67\%; mp 218-220 ${ }^{\circ} \mathrm{C}$ (dioxane); I.R. (KBr) cm ${ }^{-1} 3384$, $3218\left(\mathrm{NH}, \mathrm{NH}_{2}\right), 1682,1659$ (2XCO); ${ }^{1} \mathrm{H}$ NMR (DMSO) $\delta 6.83(\mathrm{~d}, 1 \mathrm{H}$, $J=14.9 \mathrm{~Hz}$, olefinic $\mathrm{CH}$ ); $7.43-8.63$ (a set of signals, $10 \mathrm{H}$, aromatic protons, olefinic $\mathrm{CH}$ and $\mathrm{NH}-\mathrm{H}) ; 8.42(\mathrm{~s}, 1 \mathrm{H}, \mathrm{NH}-\underline{\mathrm{H}}$, exchangeable); $11.82(\mathrm{~s}, 1 \mathrm{H}, \mathrm{NH}$, exchangeable $)$. Anal. $\left(\mathrm{C}_{16} \mathrm{H}_{13} \mathrm{ClN}_{2} \mathrm{O}_{2}\right) \mathrm{C}, \mathrm{H}, \mathrm{N}$

5-Bromo-2-\{[(2E)-3-phenylprop-2-enoyl $]$ amino\}benzamides (12c): yield 98\%; mp 229-231 ${ }^{\circ} \mathrm{C}$ (dioxane); I.R. (KBr) $\mathrm{cm}^{-1} 3388$, $3217\left(\mathrm{NH}, \mathrm{NH}_{2}\right), 1682,1659$ (2XCO); ${ }^{1} \mathrm{H}$ NMR (DMSO) $\delta 6.82(\mathrm{~d}, 1 \mathrm{H}$, $J=14.9 \mathrm{~Hz}$, olefinic $\mathrm{CH}$ ); $7.43-8.58$ (a set of signals, $10 \mathrm{H}$, aromatic protons, olefinic $\mathrm{CH}$ and $\mathrm{NH}-\mathrm{H}) ; 8.44(\mathrm{~s}, 1 \mathrm{H}, \mathrm{NH}-\mathrm{H}$, exchangeable); $11.84(\mathrm{~s}, 1 \mathrm{H}, \mathrm{NH}$, exchangeable $)$. Anal. $\left(\mathrm{C}_{16} \mathrm{H}_{13} \mathrm{BrN}_{2} \mathrm{O}_{2}\right) \mathrm{C}, \mathrm{H}, \mathrm{N}$

5-Chloro-2-\{[(2E)-3-(2-chlorophenyl)prop-2-enoyl]amino\}benzamides (12d): yield $36 \%$; mp $268-270{ }^{\circ} \mathrm{C}$ (dioxane); I.R. (KBr) $\mathrm{cm}^{-1}$ 3365, $3155\left(\mathrm{NH}, \mathrm{NH}_{2}\right), 1686,1661$ (2XCO); ${ }^{1} \mathrm{H}$ NMR (DMSO) $\delta 6.90$ (d, $1 \mathrm{H}, J=15.2 \mathrm{~Hz}$ olefinic $\mathrm{CH}$ ); 7.38-8.63 (a set of signals, $9 \mathrm{H}$, aromatic protons, olefinic $\mathrm{CH}$ and $\mathrm{NH}-\mathrm{H}) ; 8.43(\mathrm{~s}, 1 \mathrm{H}$, $\mathrm{NH}-\mathrm{H}$, exchangeable); $11.92(\mathrm{~s}, 1 \mathrm{H}, \mathrm{NH}$, exchangeable). Anal. $\left(\mathrm{C}_{16} \overline{\mathrm{H}_{12}} \mathrm{Cl}_{2} \mathrm{~N}_{2} \mathrm{O}_{2}\right) \mathrm{C}, \mathrm{H}, \mathrm{N}$

5-Chloro-2-\{[(2E)-3-(3-chlorophenyl)prop-2-enoyl lamino\}benzamides (12e): yield 88\%; mp 260-261 ${ }^{\circ} \mathrm{C}$ (dioxane); I.R. (KBr) $\mathrm{cm}^{-1}$ 3351, 3157 (NH, NH$), 1681,1662$ (2XCO); ${ }^{1} \mathrm{H}$ NMR (DMSO) $\delta 6.97$ (d, $1 \mathrm{H}, J=16.6 \mathrm{~Hz}$, olefinic $\mathrm{CH}$ ); $7.45-8.63$ (a set of signals, $9 \mathrm{H}$, aromatic protons, olefinic $\mathrm{CH}$ and $\mathrm{NH}-\underline{\mathrm{H}}) ; 8.42(\mathrm{~s}, 1 \mathrm{H}, \mathrm{NH}-\underline{\mathrm{H}}$, exchangeable); 11.79 (s, $1 \mathrm{H}, \mathrm{NH}$, exchangeable). Anal. $\left(\mathrm{C}_{16} \mathrm{H}_{12} \mathrm{Cl}_{2} \mathrm{~N}_{2} \mathrm{O}_{2}\right) \mathrm{C}, \mathrm{H}, \mathrm{N}$ 
Table 3

Overview of the results of the in vitro antitumor screening for compounds $12 \mathbf{a}-\mathbf{c}$ and $\mathbf{1 7 t}, \mathbf{u}{ }^{\mathrm{a}}$

\begin{tabular}{|c|c|c|c|c|c|c|c|c|c|c|}
\hline \multirow[b]{2}{*}{ Comp } & \multirow[t]{2}{*}{ no. Studied ${ }^{\mathrm{e}}$} & \multicolumn{3}{|l|}{ pGI50 } & \multicolumn{3}{|l|}{ pTGI $^{\mathrm{c}}$} & \multicolumn{3}{|l|}{$\mathrm{pLC}^{2 \mathrm{~d}}$} \\
\hline & & $\begin{array}{l}\text { no. giving positive } \\
\text { results }^{\mathrm{e}}\end{array}$ & range & $\overline{\text { MG_MID }}$ & $\begin{array}{l}\text { no. giving positive } \\
\text { results }\end{array}$ & range & $\overline{M G \_M I D f}$ & $\begin{array}{l}\text { no. giving positive } \\
\text { results }\end{array}$ & range & $\overline{\text { MG_MID }}$ \\
\hline $12 a$ & 58 & 58 & $6.18-4.59$ & 5.36 & 30 & $5.53-4.00$ & 4.31 & 2 & $4.44-4.00$ & 4.01 \\
\hline $12 b$ & 58 & 58 & $6.58-4.82$ & 5.65 & 29 & $6.06-4.00$ & 4.53 & 7 & $5.19-4.00$ & 4.06 \\
\hline $12 c$ & 52 & 52 & $6.64-5.47$ & 5.99 & 23 & $6.18-4.00$ & 4.58 & 10 & $5.02-4.00$ & 4.07 \\
\hline $17 t$ & 59 & 59 & $7.27-4.67$ & 6.05 & 44 & $6.41-4.00$ & 4.71 & 17 & $4.94-4.00$ & 4.10 \\
\hline $17 u$ & 57 & 57 & $6.78-4.41$ & 5.97 & 32 & $6.17-4.00$ & 4.62 & 8 & $4.90-4.00$ & 4.05 \\
\hline
\end{tabular}

a Data obtained from the NCl's in vitro disease-oriented human tumor cells screen.

b pGI50 is the - log of the molar concentration that inhibits 50\% net cell growth.

c pTGI is the -Log of the molar concentration giving total growth inhibition.

d pLC50 is the - Log of the molar concentration leading to $50 \%$ net cell death.

e Refers to the number of cell lines.

${ }^{\mathrm{f}}$ MG_MID = mean graph midpoint = arithmetical mean value for all tested cancer cell lines. If the indicated effect was not attainable within the used concentration interval, the highest tested concentration was used for the calculation.

5-Chloro-2-\{[(2E)-3-(4-chlorophenyl)prop-2-enoyl]amino\}benzamides (12f): yield 58\%; mp 243-244 ${ }^{\circ} \mathrm{C}$ (dioxane); I.R. (KBr) $\mathrm{cm}^{-1}$ 3356, 3283, $3177\left(\mathrm{NH}, \mathrm{NH}_{2}\right), 1675,1661$ (2XCO); ${ }^{1} \mathrm{H}$ NMR (DMSO) $\delta 6.87(\mathrm{~d}, 1 \mathrm{H}, J=14.9 \mathrm{~Hz}$, olefinic $\mathrm{CH}$ ); 7.47-8.62 (a set of signals,

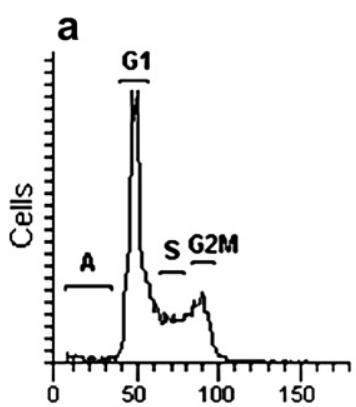

Fluorescence

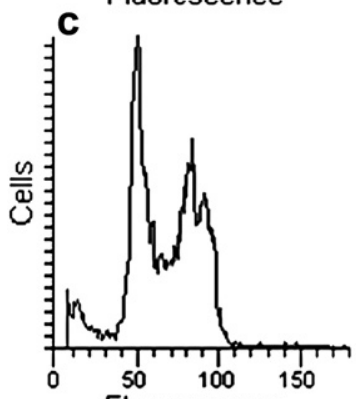

Fluorescence

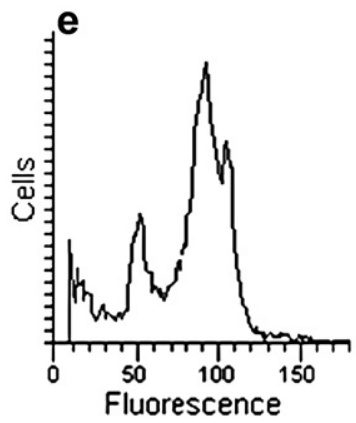

Fig. 2. Effects of compound 17t on DNA content/cell following treatment of K562 cells for $24 \mathrm{~h}$. The cells were cultured without compound (control, a), with an antimitotic drug used as internal standard (60 nM taxol (b)) and with $1 \mu \mathrm{M}(\mathrm{c}), 2 \mu \mathrm{M}$ (d), or $4 \mu \mathrm{M}$ (e) 17t. Cell cycle distribution was analyzed by the standard propidium iodide procedure as described in Materials and Methods. Sub-G0-G1 (A), G0-G1, S, and G2-M cells are indicated in (a).
$9 \mathrm{H}$, aromatic protons, olefinic $\mathrm{CH}$ and $\mathrm{NH}-\underline{\mathrm{H}}) .8 .43(\mathrm{~s}, 1 \mathrm{H}, \mathrm{NH}-\underline{\mathrm{H}}$, exchangeable); $11.82(\mathrm{~s}, 1 \mathrm{H}, \mathrm{NH}, \quad$ exchangeable). Anal. $\left(\mathrm{C}_{16} \mathrm{H}_{12} \mathrm{Cl}_{2} \mathrm{~N}_{2} \mathrm{O}_{2}\right) \mathrm{C}, \mathrm{H}, \mathrm{N}$

2-\{[(2E)-3-(2-bromophenyl)prop-2-enoyl]amino\}benzamides

(12g): yield 66\%; mp $261-262{ }^{\circ} \mathrm{C}$ (dioxane); I.R. (KBr) $\mathrm{cm}^{-1} 3366$, $3157\left(\mathrm{NH}, \mathrm{NH}_{2}\right), 1686,1662(2 \mathrm{XCO}) ;{ }^{1} \mathrm{H}$ NMR (DMSO) $\delta 6.87(\mathrm{~d}, 1 \mathrm{H}$, $J=14.8 \mathrm{~Hz}$, olefinic $\mathrm{CH}$ ); 7.35-8.63 (a set of signals, $9 \mathrm{H}$, aromatic protons, olefinic $\mathrm{CH}$ and $\mathrm{NH}-\mathrm{H}) ; 8.43(\mathrm{~s}, 1 \mathrm{H}, \mathrm{NH}-\mathrm{H}$, exchangeable); 11.90 (s, $1 \mathrm{H}, \mathrm{NH}$, exchangeable). Anal. $\left(\mathrm{C}_{16} \mathrm{H}_{12} \mathrm{BrClN}_{2} \mathrm{O}_{2}\right) \mathrm{C}, \mathrm{H}, \mathrm{N}$

2-\{[(2E)-3-(3-bromophenyl)prop-2-enoyl]amino\}benzamides (12h): yield 91\%; mp 251-252 ${ }^{\circ} \mathrm{C}$ (dioxane); I.R. (KBr) $\mathrm{cm}^{-1} 3349$, $3167\left(\mathrm{NH}, \mathrm{NH}_{2}\right), 1678,1662$ (2XCO); ${ }^{1} \mathrm{H}$ NMR (DMSO) $\delta 6.96(\mathrm{~d}, 1 \mathrm{H}$, $J=15.1 \mathrm{~Hz}$, olefinic $\mathrm{CH}$ ); 7.34-8.64 (a set of signals, 9H, aromatic protons, olefinic $\mathrm{CH}$ and $\mathrm{NH}-\mathrm{H}) ; 8.43(\mathrm{~s}, 1 \mathrm{H}, \mathrm{NH}-\mathrm{H}$, exchangeable); 11.80 (s, $1 \mathrm{H}, \mathrm{NH}$, exchangeable $)$. Anal. $\left(\mathrm{C}_{16} \mathrm{H}_{12} \mathrm{BrClN}_{2} \mathrm{O}_{2}\right) \mathrm{C}, \mathrm{H}, \mathrm{N}$

5-Chloro-2-\{[(2E)-3-(2-methylphenyl)prop-2-enoyl]amino\}benzamides (12i): yield $42 \%$; mp $231-232{ }^{\circ} \mathrm{C}$ (dioxane); I.R. ( $\left.\mathrm{KBr}\right) \mathrm{cm}^{-1}$ $3383,3165\left(\mathrm{NH}, \mathrm{NH}_{2}\right), 1687,1660$ (2XCO); ${ }^{1} \mathrm{H}$ NMR (DMSO) $\delta 2.34$ (s, $\left.3 \mathrm{H}, \mathrm{CH}_{3}\right) ; 6.66(\mathrm{~d}, 1 \mathrm{H}, J=15.6 \mathrm{~Hz}$, olefinic $\mathrm{CH}) ; 7.28-8.42$ (a set of signals, $9 \mathrm{H}$, aromatic protons, olefinic $\mathrm{CH}$ and $\mathrm{NH}-\underline{\mathrm{H}}) ; 8.42(\mathrm{~s}, 1 \mathrm{H}$, $\mathrm{NH}-\mathrm{H}$, exchangeable); $11.89(\mathrm{~s}, 1 \mathrm{H}, \mathrm{NH}$, exchangeable). Anal. $\left(\mathrm{C}_{17} \overline{\mathrm{H}_{15}} \mathrm{ClN}_{2} \mathrm{O}_{2}\right) \mathrm{C}, \mathrm{H}, \mathrm{N}$

5-Chloro-2-\{[(2E)-3-(3-methylphenyl)prop-2-enoyl]amino\}benzamides (12j): yield 82\%; mp 238-239 ${ }^{\circ} \mathrm{C}$ (dioxane); I.R. ( $\left.\mathrm{KBr}\right) \mathrm{cm}^{-1}$ $3337,3163\left(\mathrm{NH}, \mathrm{NH}_{2}\right), 1681,1660$ (2XCO); ${ }^{1} \mathrm{H}$ NMR (DMSO) $\delta 2.34(\mathrm{~s}$, $\left.3 \mathrm{H}, \mathrm{CH}_{3}\right) ; 6.80(\mathrm{~d}, 1 \mathrm{H}, J=15.4 \mathrm{~Hz}$, olefinic $\mathrm{CH}$ ); 7.21-8.65 (a set of signals, $9 \mathrm{H}$, aromatic protons, olefinic $\mathrm{CH}$ and $\mathrm{NH}-\mathrm{H}) ; 8.43(\mathrm{~s}, 1 \mathrm{H}$, $\mathrm{NH}-\mathrm{H}$, exchangeable); $11.83(\mathrm{~s}, 1 \mathrm{H}, \mathrm{NH}$, exchangeable). Anal. $\left(\mathrm{C}_{17} \overline{\mathrm{H}_{15}} \mathrm{ClN}_{2} \mathrm{O}_{2}\right) \mathrm{C}, \mathrm{H}, \mathrm{N}$

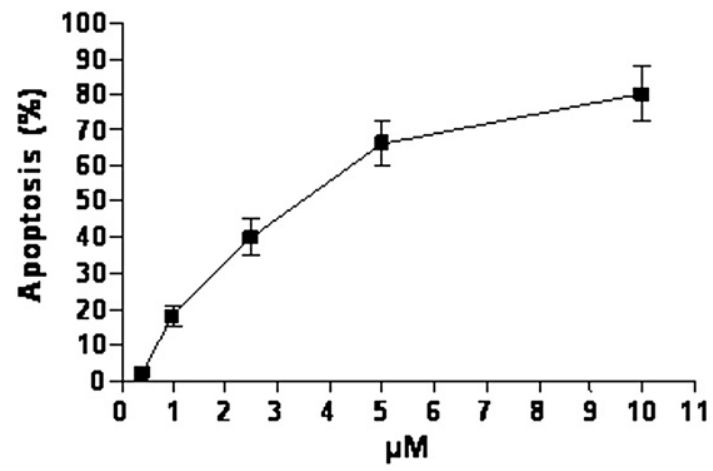

Fig. 3. Percentage of apoptosis induced by compound 17t in K562 cells. Cells were cultured with different concentrations of 17t. Apoptosis was evaluated after $48 \mathrm{~h}$ of treatment as described in the experimental section. Bars: $\pm \mathrm{SE}$. 
A

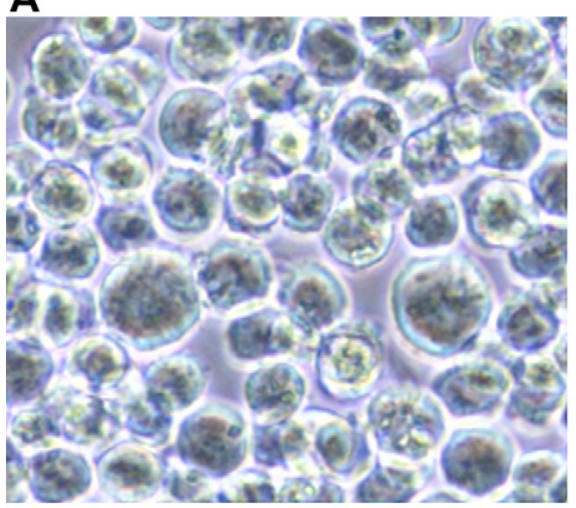

C

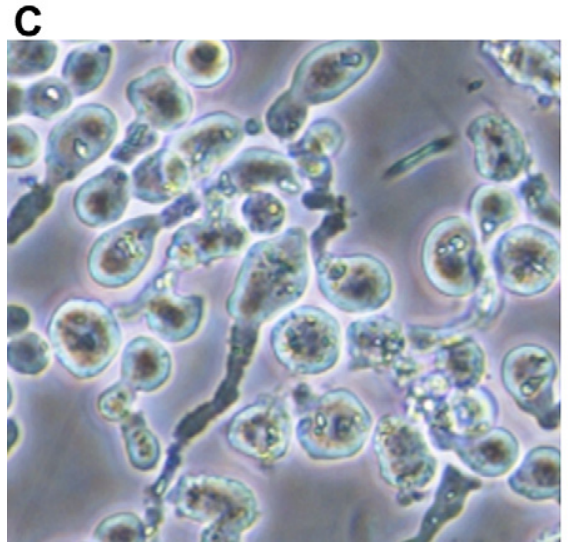

B

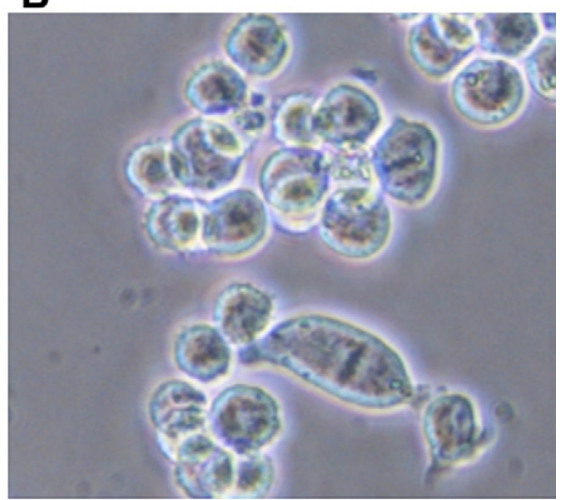

D

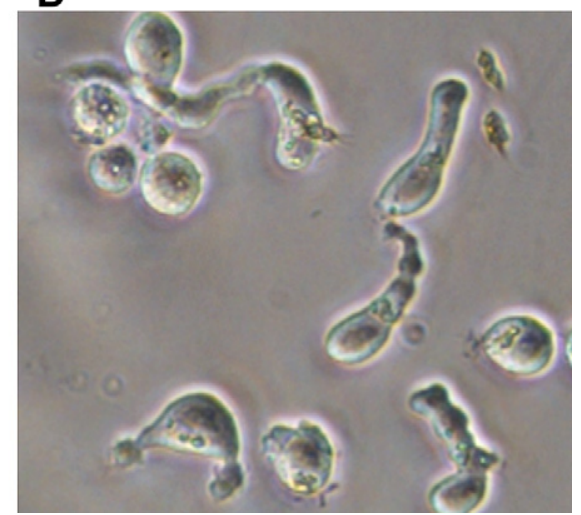

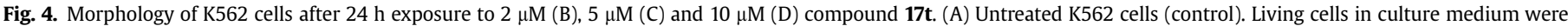
observed by using a phase contrast invertoscope ( $40 \times$ magnification).

5-Chloro-2-\{[(2E)-3-(4-methylphenyl)prop-2-enoyl lamino\}benzamides (12k): yield 82\%; mp 238-239 ${ }^{\circ} \mathrm{C}$ (dioxane); I.R. (KBr) $\mathrm{cm}^{-1}$ $3379,3212\left(\mathrm{NH}, \mathrm{NH}_{2}\right), 1682,1660$ (2XCO); ${ }^{1} \mathrm{H}$ NMR (DMSO) $\delta 2.34$ (s, $\left.3 \mathrm{H}, \mathrm{CH}_{3}\right) ; 6.78(\mathrm{~d}, 1 \mathrm{H}, J=15.2 \mathrm{~Hz}$, olefinic $\mathrm{CH}$ ); 7.23-8.62 (a set of signals, $9 \mathrm{H}$, aromatic protons, olefinic $\mathrm{CH}$ and $\mathrm{NH}-\mathrm{H}) ; 8.43(\mathrm{~s}, 1 \mathrm{H}$, $\mathrm{NH}-\mathrm{H}$, exchangeable); $11.77(\mathrm{~s}, 1 \mathrm{H}, \mathrm{NH}$, exchangeable). Anal. $\left(\mathrm{C}_{17} \overline{\mathrm{H}_{15}} \mathrm{ClN}_{2} \mathrm{O}_{2}\right) \mathrm{C}, \mathrm{H}, \mathrm{N}$

5-Bromo-2-\{[(2E)-3-(2-chlorophenyl)prop-2-enoyl]amino\}benzamides (121): yield 73\%; mp 250-251 ${ }^{\circ} \mathrm{C}$ (dioxane); I.R. (KBr) $\mathrm{cm}^{-1}$ 3366, $3153\left(\mathrm{NH}, \mathrm{NH}_{2}\right), 1685,1661$ (2XCO); ${ }^{1} \mathrm{H}$ NMR (DMSO) $\delta 6.91$ (d, $1 \mathrm{H}, J=15.1 \mathrm{~Hz}$, olefinic $\mathrm{CH}$ ); 7.42-8.02 (a set of signals, $9 \mathrm{H}$, aromatic protons, olefinic $\mathrm{CH}$ and $\mathrm{NH}-\underline{\mathrm{H}}) ; 8.42(\mathrm{~s}, 1 \mathrm{H}, \mathrm{NH}-\mathrm{H}$, exchangeable); 11.90 (s, $1 \mathrm{H}, \mathrm{NH}$, exchangeable). Anal. $\left(\mathrm{C}_{16} \mathrm{H}_{12} \mathrm{BrClN}_{2} \mathrm{O}_{2}\right) \mathrm{C}, \mathrm{H}, \mathrm{N}$

5-Bromo-2-\{[(2E)-3-(3-chlorophenyl)prop-2-enoyl]amino\}benzamides (12m): yield 56\%; mp $260-261{ }^{\circ} \mathrm{C}$ (dioxane); I.R. (KBr) $\mathrm{cm}^{-1}$ 3352, $3154\left(\mathrm{NH}, \mathrm{NH}_{2}\right), 1680,1662$ (2XCO); ${ }^{1} \mathrm{H}$ NMR (DMSO) $\delta 6.97$ (d, $1 \mathrm{H}, J=16.0 \mathrm{~Hz}$, olefinic $\mathrm{CH}$ ); 7.45-8.58 (a set of signals, $9 \mathrm{H}$, aromatic protons, olefinic $\mathrm{CH}$ and $\mathrm{NH}-\underline{\mathrm{H}}) ; 8.44(\mathrm{~s}, 1 \mathrm{H}$, $\mathrm{NH}-\mathrm{H}$, exchangeable); 11.81 (s, $1 \mathrm{H}, \mathrm{NH}$, exchangeable). Anal. $\left(\mathrm{C}_{16} \mathrm{H}_{12} \mathrm{BrClN}_{2} \mathrm{O}_{2}\right) \mathrm{C}, \mathrm{H}, \mathrm{N}$

5-Bromo-2-\{[(2E)-3-(4-chlorophenyl)prop-2-enoyl]amino\}benzamides (12n): yield 57\%; mp 255-256 ${ }^{\circ} \mathrm{C}$ (dioxane); I.R. (KBr) $\mathrm{cm}^{-1}$ 3357, 3285, $3178\left(\mathrm{NH}, \mathrm{NH}_{2}\right), 1673,1660$ (2XCO); ${ }^{1} \mathrm{H}$ NMR (DMSO) $\delta 6.87(\mathrm{~d}, 1 \mathrm{H}, J=14.7 \mathrm{~Hz}$, olefinic $\mathrm{CH}$ ); 7.47-8.55 (a set of signals, $9 \mathrm{H}$, aromatic protons, olefinic $\mathrm{CH}$ and $\mathrm{NH}-\underline{\mathrm{H}}) ; 8.42(\mathrm{~s}, 1 \mathrm{H}$, $\mathrm{NH}-\mathrm{H}$, exchangeable); $11.79(\mathrm{~s}, 1 \mathrm{H}, \mathrm{NH}$, exchangeable). Anal. $\left(\mathrm{C}_{16} \overline{\mathrm{H}_{12}} \mathrm{BrClN}_{2} \mathrm{O}_{2}\right) \mathrm{C}, \mathrm{H}, \mathrm{N}$

5-Bromo-2-\{[(2E)-3-(2-bromophenyl)prop-2-enoyl]amino\}benzamides (120): yield 81\%; mp $258-259{ }^{\circ} \mathrm{C}$ (dioxane); I.R. (KBr) $\mathrm{cm}^{-1}$
3366, $3153\left(\mathrm{NH}, \mathrm{NH}_{2}\right), 1685,1661$ (2XCO); ${ }^{1} \mathrm{H}$ NMR (DMSO) $\delta 6.87$ (d, $1 \mathrm{H}, J=16.5 \mathrm{~Hz}$, olefinic $\mathrm{CH}$ ); 7.71-8.52 (a set of signals, $9 \mathrm{H}$, aromatic protons, olefinic $\mathrm{CH}$ and $\mathrm{NH}-\underline{\mathrm{H}}) ; 8.42(\mathrm{~s}, 1 \mathrm{H}, \mathrm{NH}-\underline{\mathrm{H}}$, exchangeable); 11.88 (s, $1 \mathrm{H}, \mathrm{NH}$, exchangeable). Anal. $\left(\mathrm{C}_{16} \mathrm{H}_{12} \mathrm{Br}_{2} \mathrm{~N}_{2} \mathrm{O}_{2}\right) \mathrm{C}, \mathrm{H}, \mathrm{N}$

5-Bromo-2-\{[(2E)-3-(3-bromophenyl)prop-2-enoyl]amino\}benzamides (12p): yield 81\%; mp $258-259{ }^{\circ} \mathrm{C}$ (dioxane); I.R. (KBr) cm $\mathrm{cm}^{-1}$ 3348, $3156\left(\mathrm{NH}, \mathrm{NH}_{2}\right), 1678,1661$ (2XCO); ${ }^{1} \mathrm{H}$ NMR (DMSO) $\delta 6.97$ (d, $1 \mathrm{H}, J=15.6 \mathrm{~Hz}$, olefinic $\mathrm{CH}$ ); 7.35-8.56 (a set of signals, $9 \mathrm{H}$, aromatic protons, olefinic $\mathrm{CH}$ and $\mathrm{NH}-\underline{\mathrm{H}}) ; 8.43(\mathrm{~s}, 1 \mathrm{H}, \mathrm{NH}-\underline{\mathrm{H}}$, exchangeable); $11.78(\mathrm{~s}, 1 \mathrm{H}, \mathrm{NH}$, exchangeable). Anal. $\left(\mathrm{C}_{16} \mathrm{H}_{12} \mathrm{Br}_{2} \mathrm{~N}_{2} \mathrm{O}_{2}\right) \mathrm{C}, \mathrm{H}, \mathrm{N}$

5-Bromo-2-\{[(2E)-3-(2-methylphenyl)prop-2-enoyl]amino $\}$ benzamides (12q): yield 98\%; $\mathrm{mp} 238-240{ }^{\circ} \mathrm{C}$ (dioxane); I.R. (KBr) $\mathrm{cm}^{-1}$ $3384,3160\left(\mathrm{NH}, \mathrm{NH}_{2}\right), 1686,1659$ (2XCO); ${ }^{1} \mathrm{H}$ NMR (DMSO) $\delta 2.32(\mathrm{~s}$, $\left.3 \mathrm{H}, \mathrm{CH}_{3}\right) ; 6.74(\mathrm{~d}, 1 \mathrm{H}, \mathrm{J}=15.4 \mathrm{~Hz}$, olefinic $\mathrm{CH}) ; 7.25-8.56$ (a set of signals, $9 \mathrm{H}$, aromatic protons, olefinic $\mathrm{CH}$ and $\mathrm{NH}-\mathrm{H}) ; 8.42(\mathrm{~s}, 1 \mathrm{H}$, $\mathrm{NH}-\mathrm{H}$, exchangeable); 11.89 (s, $1 \mathrm{H}, \mathrm{NH}$, exchangeable). Anal. $\left(\mathrm{C}_{17} \overline{\mathrm{H}}_{15} \mathrm{BrN}_{2} \mathrm{O}_{2}\right) \mathrm{C}, \mathrm{H}, \mathrm{N}$

5-Bromo-2-\{[(2E)-3-(3-methylphenyl)prop-2-enoyllamino $\}$ benzamides (12r): yield $71 \%$; $\mathrm{mp} 268-270{ }^{\circ} \mathrm{C}$ (dioxane); I.R. $(\mathrm{KBr}) \mathrm{cm}^{-1}$ 3338, $3163\left(\mathrm{NH}, \mathrm{NH}_{2}\right), 1681,1661$ (2XCO); ${ }^{1} \mathrm{H}$ NMR (DMSO) $\delta 2.34$ (s, $\left.3 \mathrm{H}, \mathrm{CH}_{3}\right) ; 6.80(\mathrm{~d}, 1 \mathrm{H}, J=16.5 \mathrm{~Hz}$, olefinic $\mathrm{CH}) ; 7.24-8.63$ (a set of signals, $9 \mathrm{H}$, aromatic protons, olefinic $\mathrm{CH}$ and $\mathrm{NH}-\mathrm{H}) ; 8.42(\mathrm{~s}, 1 \mathrm{H}$, $\mathrm{NH}-\underline{\mathrm{H}}$, exchangeable); $11.80(\mathrm{~s}, 1 \mathrm{H}, \mathrm{NH}$, exchangeable). Anal. $\left(\mathrm{C}_{17} \mathrm{H}_{15} \mathrm{BrN}_{2} \mathrm{O}_{2}\right) \mathrm{C}, \mathrm{H}, \mathrm{N}$

5-Bromo-2-\{[(2E)-3-(4-methylphenyl)prop-2-enoyl]amino\}benzamides (12s): yield $88 \%$; mp $236-237^{\circ} \mathrm{C}$ (dioxane); I.R. (KBr) cm $\mathrm{cm}^{-1}$ $3353,3163\left(\mathrm{NH}, \mathrm{NH}_{2}\right), 1678,1660$ (2XCO); ${ }^{1} \mathrm{H}$ NMR (DMSO) $\delta 2.33$ (s, $\left.3 \mathrm{H}, \mathrm{CH}_{3}\right) ; 6.75(\mathrm{~d}, 1 \mathrm{H}, J=14.8 \mathrm{~Hz}$, olefinic $\mathrm{CH}$ ); $7.22-8.56$ (a set of 

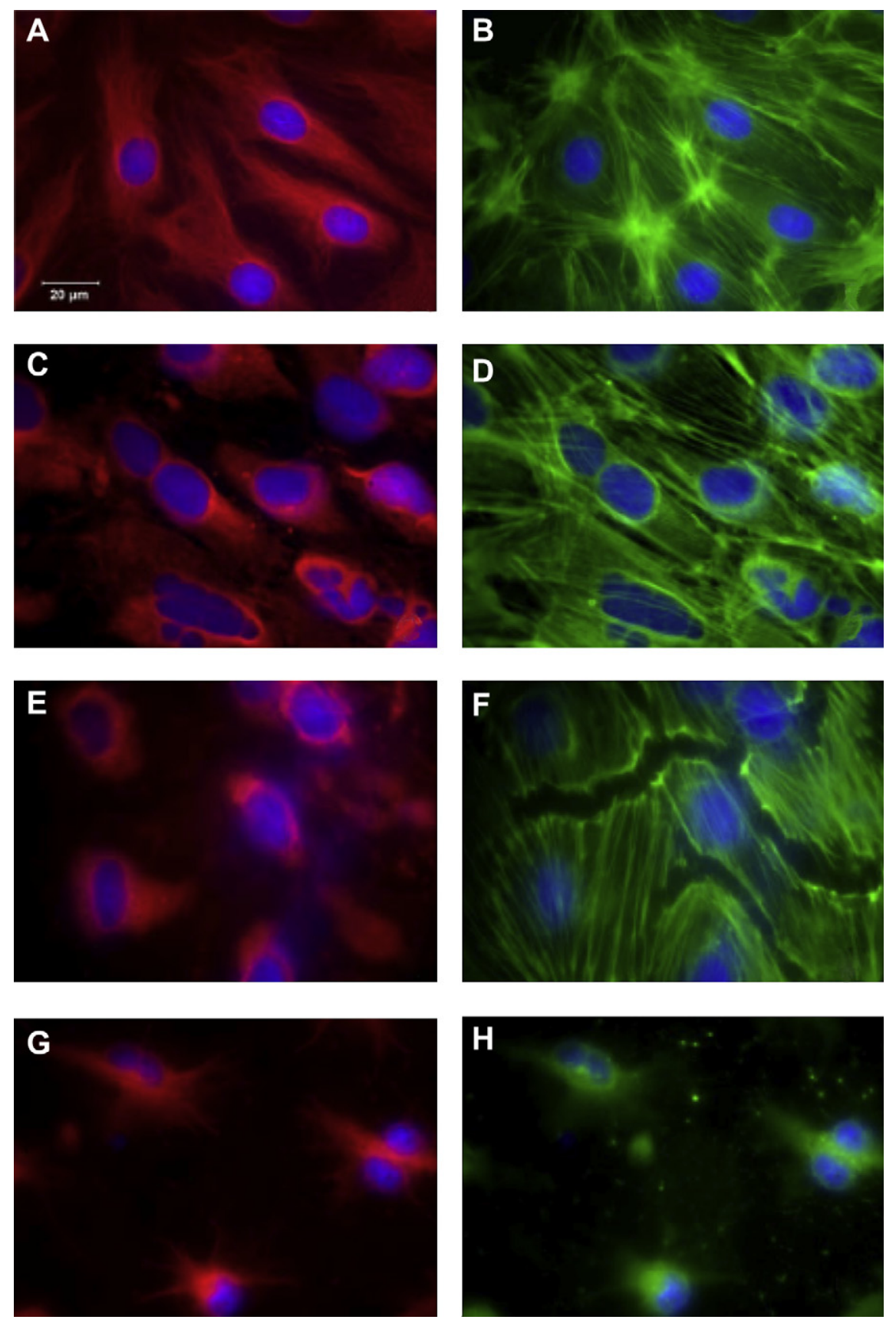

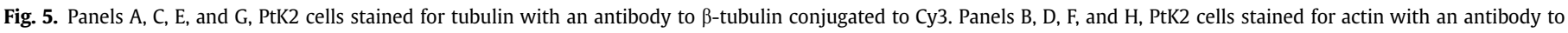

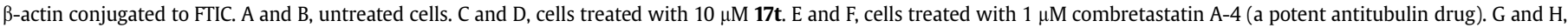
cells treated with $1 \mu \mathrm{M}$ latrunculin A (a potent inhibitor of actin assembly).

signals, 9H, aromatic protons, olefinic $\mathrm{CH}$ and $\mathrm{NH}-\underline{\mathrm{H}}) ; 8.42(\mathrm{~s}, 1 \mathrm{H}$, $\mathrm{NH}-\mathrm{H}$, exchangeable); $11.78(\mathrm{~s}, 1 \mathrm{H}, \mathrm{NH}$, exchangeable). Anal. $\left(\mathrm{C}_{17} \overline{\mathrm{H}_{15}} \mathrm{BrN}_{2} \mathrm{O}_{2}\right) \mathrm{C}, \mathrm{H}, \mathrm{N}$

\subsubsection{General procedure for preparation of 2-cinnamamido-5-} iodobenzoic acids $\mathbf{1 5 t}-\boldsymbol{v}$

To an ice cooled $\left(0-5{ }^{\circ} \mathrm{C}\right)$ stirred solution of 2-amino-5-iodobenzoic acid 13 ( $3 \mathrm{mmol}$ ) in anhydrous pyridine $(20 \mathrm{ml}) 2 \mathrm{mmol}$ of cinnamoyl chlorides $\mathbf{1 1 t}-\mathbf{v}$ was added. The solution was left stirring overnight, then poured into cold water. The precipitate was collected as a mixture of (E)-6-iodo-2-styryl-4H-benzo[d] [1,3] oxazin-4-ones $\mathbf{1 4 t}-\mathbf{u}$ and 2-cinnamamido-5-iodobenzoic acids 15t-v. The mixture was refluxed in $0.01 \mathrm{M}$ aqueous $\mathrm{Na}_{3} \mathrm{PO}_{4}$ for $20 \mathrm{~h}$. The solution was allowed to cool to room temperature and, after filtration, was acidified with $\mathrm{HCl}(0.1 \mathrm{M})$ to $\mathrm{pH} 2$ to give the corresponding acids $\mathbf{1 5 t}$ [10] and $\mathbf{1 5 u}$ as the only products. Finally, the precipitate was removed by filtration and washed with cold chloroform to obtain pure 15t,u. In the case of cinnamoyl chloride $11 \mathrm{v}$, treatment with 2-amino-5-iodobenzoic acid 13 (3 mmol) in anhydrous pyridine $(20 \mathrm{ml})$ directly gave pure $(E)-5$-iodo-2-(3-otolylacrylamido)benzoic acid $\mathbf{1 5 v}$.

(E)-2-(3-(2-chlorophenyl)acrylamido)-5-iodobenzoic acid (15u): yield 80\%; mp 250-252 ${ }^{\circ} \mathrm{C}$ (ethanol); I.R. (KBr) $\mathrm{cm}^{-1} 3448,3117$ $(\mathrm{NH}, \mathrm{OH}), 1703,1688$ (2XCO); ${ }^{1} \mathrm{H}$ NMR (DMSO) $\delta 6.94$ (d, 1H, 


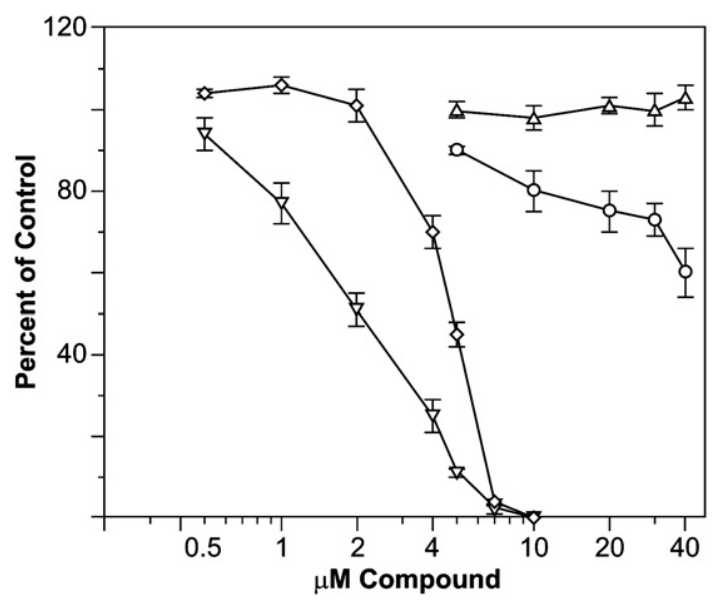

Fig. 6. Comparison of the effects of $\mathbf{1 7 t}$ with those of colchicine as an inhibitor of the polymerization of purified tubulin. Assembly was followed in Gilford model 250 recording spectrophotometers equipped with electronic temperature controllers. Reaction mixtures were preincubated at $30{ }^{\circ} \mathrm{C}$ without GTP and chilled on ice. GTP $(0.4 \mathrm{mM})$ was added to the samples, which were transferred to cuvettes held at $0{ }^{\circ} \mathrm{C}$. Baselines were established, and the temperature was jumped to $30^{\circ} \mathrm{C}$ over about $60 \mathrm{~s}$ and held there for $20 \mathrm{~min}$. Maximal reaction rates and extent of assembly were determined for each sample and compared to a control reaction mixture in the same experiment. Each data point was obtained in triplicate, and standard deviations are shown. Symbols as follows: o, maximum rates obtained with 17t; $\Delta$, extents of reaction obtained with 17t; $\nabla$, maximum rates obtained with colchicine; $\diamond$, extents of reaction obtained with colchicine.

$J=15.3 \mathrm{~Hz}$, olefinic $\mathrm{CH}$ ); 7.44-8.43 (a set of signals, $8 \mathrm{H}$, aromatic protons, olefinic $\mathrm{CH}) ; 11.37(\mathrm{~s}, 1 \mathrm{H}, \mathrm{NH}-\mathrm{H}$, exchangeable); 13.98 (s, $1 \mathrm{H}, \mathrm{OH}$, exchangeable). Anal. $\left(\mathrm{C}_{16} \mathrm{H}_{11} \mathrm{ClIN}_{3}\right) \mathrm{C}, \mathrm{H}, \mathrm{N}$

(E)-5-iodo-2-(3-o-tolylacrylamido)benzoic acid (15v): yield 83\%; mp 239-240 ${ }^{\circ} \mathrm{C}$ (ethanol); I.R. (KBr) $\mathrm{cm}^{-1} 3353,3163\left(\mathrm{NH}, \mathrm{NH}_{2}\right)$, 1678, 1660 (2XCO); ${ }^{1} \mathrm{H}$ NMR (DMSO) $\delta 2.37$ (s, 3H, $\left.\mathrm{CH}_{3}\right) ; 6.82(\mathrm{~d}, 1 \mathrm{H}$, $J=15.3 \mathrm{~Hz}$, olefinic $\mathrm{CH}$ ); 7.27-8.48 (a set of signals, $8 \mathrm{H}$, aromatic protons, olefinic $\mathrm{CH}$ ); 11.28 (s, $1 \mathrm{H}, \mathrm{NH}-\underline{\mathrm{H}}$, exchangeable); 13.90 (s, $1 \mathrm{H}, \mathrm{OH}$, exchangeable). Anal. $\left(\mathrm{C}_{17} \mathrm{H}_{14} \mathrm{INO}_{3}\right) \mathrm{C}, \mathrm{H}, \mathrm{N}$

\subsubsection{General procedure for preparation of 6-iodo-1H-benzo[d] [1,3]oxazine-2,4-diones $\mathbf{1 6 t}-\boldsymbol{v}$}

A mixture of 2-cinnamamido-5-iodobenzoic acids $15 \mathbf{t}-\mathbf{v}$ ( $4.6 \mathrm{mmol})$ and ethylchloroformate $(25 \mathrm{ml}$ ) was refluxed for $15 \mathrm{~min}$. After this time, acetyl chloride $(1.5 \mathrm{ml})$ was added, and reflux continued for an additional $30 \mathrm{~min}$. On cooling, the product precipitated, was removed by filtration, and was washed with chloroform to give pure $16 \mathbf{t}-\mathbf{v}$. Compound $\mathbf{1 6 v}$ easily decomposed and was used as is without purification.

1-Cinnamoyl-6-iodo-1H-benzo[d] [1,3] oxazine-2,4-dione (16t): yield 83\%; mp 201-204 ${ }^{\circ} \mathrm{C}\left(\mathrm{CHCl}_{3}\right)$; I.R. $(\mathrm{KBr}) \mathrm{cm}^{-1} 1760,1670$ (3XCO); ${ }^{1} \mathrm{H}$ NMR (DMSO) $\delta 6.96(\mathrm{~d}, 1 \mathrm{H}, J=16 \mathrm{~Hz}$, olefinic $\mathrm{CH}$ ); 7.39-8.42 (a set of signals, 9H, aromatic protons and olefinic $\mathrm{C}$ ). Anal. $\left(\mathrm{C}_{17} \mathrm{H}_{10} \mathrm{INO}_{4}\right) \mathrm{C}, \mathrm{H}, \mathrm{N}$

(E)-1-(3-(2-chlorophenyl)acryloyl)-6-iodo-1H-benzo[d] [1,3]oxazine-2,4-dione (16u): yield 83\%; mp 201-204 ${ }^{\circ} \mathrm{C}\left(\mathrm{CHCl}_{3}\right)$; I.R. ( $\left.\mathrm{KBr}\right)$ $\mathrm{cm}^{-1} 1760,1660$ (3XCO); ${ }^{1} \mathrm{H}$ NMR (DMSO) $\delta 7.01(\mathrm{~d}, 1 \mathrm{H}, J=16 \mathrm{~Hz}$, olefinic $\mathrm{CH}$ ); $7.38-8.33$ (a set of signals, $8 \mathrm{H}$, aromatic protons and olefinic C). Anal. $\left(\mathrm{C}_{17} \mathrm{H}_{9} \mathrm{IClNO}_{4}\right) \mathrm{C}, \mathrm{H}, \mathrm{N}$

\subsubsection{General procedure for preparation of 2-cinnamamido-5-iodo- benzamides $17 \mathrm{t}-\boldsymbol{v}$}

A solution of 6-iodo-1H-benzo[d] [1,3]oxazine-2,4-diones 16t-v (2.3 $\mathrm{mmol}), 25 \%$ aqueous ammonia solution $(28 \mathrm{ml})$ and dioxane $(5 \mathrm{ml})$ was left under reflux for $3 \mathrm{~h}$. After this time, the solution was kept in a freezer to allow the product to precipitate. It was removed by filtration and crystallized from dioxane.
5-iodo-2-\{[(2E)-3-phenylprop-2-enoyl]amino\}benzamide (17t): yield 88\%; mp 260-261 ${ }^{\circ} \mathrm{C}$ (dioxane); I.R. (KBr) $\mathrm{cm}^{-1} 3393,3215$ $\left(\mathrm{NH}, \mathrm{NH}_{2}\right), 1680,1656$ (2XCO); ${ }^{1} \mathrm{H}$ NMR (DMSO) $\delta 6.82(\mathrm{~d}, 1 \mathrm{H}$, $J=15.6 \mathrm{~Hz}$, olefinic $\mathrm{CH}$ ); $7.43-8.42$ (a set of signals, $10 \mathrm{H}$, aromatic protons, olefinic $\mathrm{CH}$ and $\mathrm{NH}-\mathrm{H}) ; 8.15(\mathrm{~s}, 1 \mathrm{H}, \mathrm{NH}-\mathrm{H}$, exchangeable); $11.80(\mathrm{~s}, 1 \mathrm{H}, \mathrm{NH}$, exchangeable $)$. Anal. $\left(\mathrm{C}_{16} \mathrm{H}_{13} \mathrm{IN}_{2} \overline{\mathrm{O}}_{2}\right) \mathrm{C}, \mathrm{H}, \mathrm{N}$

5-Iodo-2-\{[(2E)-3-(2-chlorophenyl)prop-2-enoyl]amino\}benzamides (17u): yield 88\%; mp 260-261 ${ }^{\circ} \mathrm{C}$ (dioxane); I.R. (KBr) cm $\mathrm{cm}^{-1} 3381,3155$ $\left(\mathrm{NH}, \mathrm{NH}_{2}\right), 1681,1660$ (2XCO); ${ }^{1} \mathrm{H}$ NMR (DMSO) $\delta 6.97(\mathrm{~d}, 1 \mathrm{H}$, $J=16.6 \mathrm{~Hz}$, olefinic $\mathrm{CH}$ ); 7.45-8.63 (a set of signals, $9 \mathrm{H}$, aromatic protons, olefinic $\mathrm{CH}$ and $\mathrm{NH}-\underline{\mathrm{H}}) ; 8.42(\mathrm{~s}, 1 \mathrm{H}, \mathrm{NH}-\underline{\mathrm{H}}$, exchangeable); 11.79 (s, $1 \mathrm{H}, \mathrm{NH}$, exchangeable $)$. Anal. $\left(\mathrm{C}_{16} \mathrm{H}_{12} \mathrm{ClIN}_{2} \overline{\mathrm{O}_{2}}\right) \mathrm{C}, \mathrm{H}, \mathrm{N}$

5-iodo-2-\{[(2E)-3-(2-methylphenyl)prop-2-enoyl]amino\}benzamide (17v): yield 88\%; $\mathrm{mp} 260-261{ }^{\circ} \mathrm{C}$ (dioxane); I.R. (KBr) $\mathrm{cm}^{-1}$ 3368, 3294, $3192\left(\mathrm{NH}, \mathrm{NH}_{2}\right), 1673,1658$ (2XCO); ${ }^{1} \mathrm{H}$ NMR (DMSO) $\delta 2.34\left(\mathrm{~s}, 3 \mathrm{H}, \mathrm{CH}_{3}\right) ; 6.97(\mathrm{~d}, 1 \mathrm{H}, J=16.6 \mathrm{~Hz}$, olefinic $\mathrm{CH}) ; 7.45-8.63(\mathrm{a}$ set of signals, $9 \mathrm{H}$, aromatic protons, olefinic $\mathrm{CH}$ and $\mathrm{NH}-\mathrm{H}) ; 8.14$ (s, $1 \mathrm{H}, \mathrm{NH}-\mathrm{H}$, exchangeable); 11.77 (s, $1 \mathrm{H}, \mathrm{NH}$, exchangeable). Anal. $\left(\mathrm{C}_{17} \mathrm{H}_{15} \mathrm{IN}_{2} \mathrm{O}_{2}\right) \mathrm{C}, \mathrm{H}, \mathrm{N}$

\subsection{Biology}

\subsubsection{Antiproliferative activity}

Compounds $12 \mathbf{a}-\mathbf{s}$ and $\mathbf{1 7 t}-\mathbf{v}$ were initially tested in vitro for antiproliferative activity against the K562 (human chronic myelogenous leukemia) cell line. These cell lines were grown at $37{ }^{\circ} \mathrm{C}$ in a humidified atmosphere containing $5 \% \mathrm{CO}_{2}$, in RPMI-1640 medium supplemented with $10 \%$ fetal bovine serum and antibiotics.

K562 cells were suspended at a density of $1 \times 10^{5}$ cells $/ \mathrm{ml}$ in growth medium, transferred to a 24 -well plate $(1 \mathrm{ml} /$ well $)$, cultured with or without (in the case of control wells) a screening concentration of $10 \mu \mathrm{M}$ compounds and incubated at $37{ }^{\circ} \mathrm{C}$ for $48 \mathrm{~h}$. Numbers of viable cells were determined by counting in a hematocytometer after dye exclusion with trypan blue [17]. The antiproliferative effects of the compounds were estimated in terms of \% growth inhibition, comparing cell viability of treated and untreated cells. We determined IC50 values (test agent concentration at which the cell proliferation was inhibited by $50 \%$ as compared with the untreated control) for compounds that exhibited the best activity at the screening concentration.

\subsubsection{Tumor cell line screening}

The in vitro antiproliferative activity values were obtained by the Developmental Therapeutics Program, National Cancer Institute (USA) [18]

The human tumor cell lines of the cancer screening panel are grown in RPMI 1640 medium containing 5\% fetal bovine serum and $2 \mathrm{mM}$ L-glutamine. For a typical screening experiment, cells are inoculated into 96 well microtiter plates in $100 \mu \mathrm{l}$ at plating densities ranging from 5000 to 40,000 cells/well, depending on the doubling time of the individual cell lines. After cell inoculation, the microtiter plates are incubated at $37{ }^{\circ} \mathrm{C}, 5 \% \mathrm{CO}_{2}, 95 \%$ air and $100 \%$ relative humidity for $24 \mathrm{~h}$ prior to addition of experimental drugs. After $24 \mathrm{~h}$, two plates of each cell line are fixed in situ with TCA, to represent a measurement of the cell population for each cell line at the time of drug addition (Tz). Experimental drugs are solubilized in dimethyl sulfoxide at 400 -fold the desired final maximum test concentration and stored frozen prior to use. At the time of drug addition, an aliquot of frozen concentrate is thawed and diluted to twice the desired final maximum test concentration with complete medium containing $50 \mu \mathrm{g} / \mathrm{ml}$ gentamicin. Additional four, 10 -fold or $1 / 2 \log$ serial dilutions are made to provide a total of five drug concentrations plus control. Aliquots of $100 \mu \mathrm{l}$ of these different drug dilutions are added to the appropriate microtiter wells already containing $100 \mu \mathrm{l}$ of medium, resulting in the required final drug 
concentrations. Following drug addition, the plates are incubated for an additional $48 \mathrm{~h}$ at $37{ }^{\circ} \mathrm{C}, 5 \% \mathrm{CO}_{2}, 95 \%$ air, and $100 \%$ relative humidity. For adherent cells, the assay is terminated by the addition of cold TCA. Cells are fixed in situ by the gentle addition of $50 \mu \mathrm{l}$ of cold $50 \%(\mathrm{w} / \mathrm{v})$ TCA (final concentration, 10\% TCA) and incubated for $60 \mathrm{~min}$ at $4{ }^{\circ} \mathrm{C}$. The supernatant is discarded, and the plates are washed five times with tap water and air dried. Sulforhodamine B (SRB) solution $(100 \mu \mathrm{l})$ at $0.4 \%(\mathrm{w} / \mathrm{v})$ in $1 \%$ acetic acid is added to each well, and plates are incubated for $10 \mathrm{~min}$ at room temperature. After staining, unbound dye is removed by washing five times with $1 \%$ acetic acid, and the plates are air dried. Bound stain is subsequently solubilized with $10 \mathrm{mM}$ trizma base, and the absorbance is read on an automated plate reader at a wavelength of $515 \mathrm{~nm}$. For suspension cells, the methodology is the same except that the assay is terminated by fixing settled cells at the bottom of the wells by gently adding $50 \mu \mathrm{l}$ of $80 \%$ TCA (final concentration, 16\% TCA). Using the seven absorbance measurements [time zero (Tz), control growth (C), and test growth in the presence of drug at the five concentration levels (Ti)], the percentage growth is calculated at each of the drug concentration levels. Percentage growth inhibition is calculated as:

$[(\mathrm{Ti}-\mathrm{Tz}) /(\mathrm{C}-\mathrm{Tz})] \times 100$ for concentrations for which $\mathrm{Ti} \geq \mathrm{Tz}$

$[(\mathrm{Ti}-\mathrm{Tz}) / \mathrm{Tz}] \times 100$ for concentrations for which $\mathrm{Ti}<\mathrm{Tz}$

Three dose response parameters are calculated for each experimental agent. Growth inhibition of $50 \%\left(\mathrm{GI}_{50}\right)$ is calculated from $[(\mathrm{Ti}-\mathrm{Tz}) /(\mathrm{C}-\mathrm{Tz})] \times 100=50$, which is the drug concentration resulting in a $50 \%$ reduction in the net protein increase (as measured by SRB staining) in control cells during the drug incubation. The drug concentration resulting in total growth inhibition (TGI) is calculated from $\mathrm{Ti}=\mathrm{Tz}$. The $\mathrm{LC}_{50}$ (concentration of drug resulting in a $50 \%$ reduction in the measured protein at the end of the drug treatment as compared to that at the beginning) indicating a net loss of cells following treatment is calculated from $[(\mathrm{Ti}-\mathrm{Tz}) / \mathrm{Tz}] \times 100=-50$. Values are calculated for each of these three parameters if the level of activity is reached; however, if the effect is not reached or is exceeded, the value for that parameter is expressed as greater or less than the maximum or minimum concentration tested.

\subsubsection{Cytotoxicity assays}

To evaluate the number of live and dead neoplastic cells, the cells were stained with trypan blue and counted on a hemocytometer. To determine the growth inhibitory activity of the drugs tested, $2 \times 10^{5}$ cells were plated into $25 \mathrm{~mm}$ wells (Costar, Cambridge, UK) in $1 \mathrm{ml}$ of complete medium and treated with different concentrations of each drug. After $48 \mathrm{~h}$ of incubation, the number of viable cells was determined and expressed as percent of control proliferation.

\subsubsection{Morphological evaluation of apoptosis}

Drug induced apoptosis was determined morphologically after labeling with acridine orange and ethidium bromide. Cells $(2 \times 105)$ were centrifuged $(300 \times \mathrm{g})$, and the pellet was resuspended in $25 \mu \mathrm{l}$ of the dye mixture. Ten $\mu \mathrm{l}$ of the mixture was examined under oil immersion with a $100 \times$ objective using a fluorescence microscope. Live cells were determined by the uptake of acridine orange (green fluorescence) and exclusion of ethidium bromide (red fluorescence) stain. Live and dead apoptotic cells were identified by perinuclear condensation of chromatin stained by acridine orange $(100 \mu \mathrm{g} / \mathrm{ml})$ or ethidium bromide $(100 \mu \mathrm{g} / \mathrm{ml})$, respectively, and by the formation of apoptotic bodies. The percentage of apoptotic cells was determined after counting at least 300 cells.

\subsubsection{Determination of apoptosis by annexin- $V$}

Cells $\left(1 \times 10^{6}\right)$ were washed with phosphate-buffered saline (PBS) and centrifuged at $200 \times \mathrm{g}$ for $5 \mathrm{~min}$. Cell pellets were suspended in $100 \mu \mathrm{l}$ of staining solution containing FITC-conjugated annexin-V and propidium iodide (Annexine-V-Fluos Staining Kit, Roche Molecular Biochemicals, Mannheim, Germany) and incubated for $15 \mathrm{~min}$ at $20^{\circ} \mathrm{C}$. Annexin-V positive cells were evaluated by flow cytometry (Becton-Dickinson.

\subsubsection{Flow cytometric analysis of cell cycle and apoptosis}

Cells were washed once in ice-cold PBS and resuspended at $1 \times 10^{6} \mathrm{ml}$ in a hypotonic fluorochrome solution containing propidium iodide (Sigma) $50 \mu \mathrm{g} / \mathrm{ml}$ in $0.1 \%$ sodium citrate plus $0.03 \%$ (v/v) nonidet P-40 (Sigma). After 30 min of incubation, the fluorescence of each sample was analyzed as a single-parameter frequency histogram using a FACScan flow cytometer (Becton-Dickinson, San Jose, CA). Distribution of cells in the cell cycle was determined using the ModFit LT program (Verity Software House, Inc.). Apoptosis was determined by evaluating the percentage of hypodiploid nuclei accumulated in the sub-G0-G1 peak after labeling with propidium iodide.

\subsubsection{Immunofluorescence}

PtK2 cells (Potorus tridactylis kidney epithelial cells) were obtained from the American Type Tissue Collection and grown as recommended by the supplier. The technique was described in detail previously $[19,20]$. Cells were treated with compounds for $24 \mathrm{~h}$ at $37{ }^{\circ} \mathrm{C}$ prior to fixation and staining with antibodies (Cy3 conjugate of anti- $\beta$-tubulin clone TUB2.1 and FTIC conjugate of anti- $\beta$-actin clone Ac-15 monoclonal antibodies from Sigma). Cells were examined with a Nikon Eclipse E800 microscope equipped with epifluorescence and appropriate filters, and images were collected with a Spot digital camera.

\subsubsection{Tubulin assembly}

The procedure with purified bovine brain tubulin was described in detail previously [21].

\section{Acknowledgment}

Financial support from MIUR (40\% funding) is gratefully acknowledged. The authors wish to thank the Developmental Therapeutics Program of the National Cancer Institute of the United States of America for performing the antiproliferative screening of compounds.

\section{References}

[1] H. Ogita, Y. Isobe, H. Takaku, R. Sekine, Y. Goto, S. Misawa, H. Hayashi, Bioorg. Med. Chem. Lett. 11 (2001) 549-551.

[2] S.J. Williams, D. Stapleton, S. Zammit, D.J. Kelly, R.E. Gilbert, H., Krum, Patent WO2008003141 (2008); Chem. Abst. 148:144415.

[3] Y. Bo, P.P. Chakrabarti, N. Chen, E.M. Doherty, C.H. Fotsch, N. Han, M.G. Kelly, Q. Liu, M.H. Norman, X. Wang, J. Zhu, Ognynanov, V., Patent W003049702 (2003); Chem. Abst. 139:53025.

[4] H. Harada, M. Isaji, H. Miyata, H. Kusama, Y. Nonaka, K. Kamata, T. Yazaki, Hotei, Y., Patent JP10330254 (1998); Chem. Abst. 130:105331.

[5] H. Harada, M. Isaji, H. Kusama, Y. Taketana, Y. Nonaka, T. Kamata, Y. Futai, Patent JP10259129 (1998); Chem. Abst. 129:321163.

[6] H. Harada, H. Kusama, Y. Nonaka, K. Kamata, Y. Fotei, Patent JP10360124 (1998); Chem. Abst. 130:47477.

[7] H. Harada, H. Kusama, Y. Nonaka, K. Kamata, Y. Hotei, A. Iyobe, H. Fujikura, F. Satoh, Patent W09709301 (1997); Chem. Abst. 126:250990.

[8] A.V. Dolzhenco-Podchezertseva, L.M. Korkodinova, M.V. Vasilyuc, V.P. Kotegov, Pharm. Chem. J. 36 (2002) 647-648. 
[9] K. Bratt, K. Sunnerheim, S. Bryngelsson, A. Fagerlund, L. Engman, R.E. Andersson, L.H. Dimberg, J. Agr. Food Chem. 51 (2003) 594-600.

[10] P. Rani, V.K. Srivastava, A. Kumar, Ind. J. Chem. B. Org. 42B (2003) 1729-1733.

[11] G.M. Coppola, Synthesis 7 (1980) 505-536

[12] S. Chimichi, F. De Sio, D. Donati, G. Fina, R. Pepino, P. Sarti-Fantoni, Heterocycles 20 (1983) 263-267.

[13] J. Hanusek, M. Sedlák, P. Šimůnek, V. Štěrba, Eur. J. Org. Chem. 11 (2002) 1855-1863.

[14] M.R. Boyd, K.D. Paull, Drug Dev. Res. 34 (1995) 91-109.

[15] K.D. Paull, C.M. Lin, L. Malspeis, E. Hamel, Cancer Res. 52 (1992) 3892-3900.
[16] M.H. Palmer, G.J. McVie, J. Chem. Soc. B (1968) 745-751.

[17] S. Manfredini, R. Bazzanini, P.G. Baraldi, M. Guarneri, D. Simoni, M.E. Marongiu, A. Pani, P. La Colla, E. Tramontano, J. Med. Chem. 35 (1992) 917-924.

[18] The methodology can be found at http://dtp.nci.nih.gov/.

[19] R. Bai, P. Verdier-Pinard, S. Gangwar, C.C. Stessman, K.J. McClure E.A. Sausville, G.R. Pettit, R.B. Bates, E. Hamel, Mol. Pharmacol. 59 (2001) 462-469.

[20] Z. Cruz-Monserrate, H.C. Vervoort, R. Bai, D.J. Newman, S.B. Howell, G. Los, J.T. Mullaney, M.D. Williams, G.R. Pettit, W. Fenical, E. Hamel, Mol. Pharmacol. 63 (2003) 1273-1280.

[21] E. Hamel, Cell Biochem. Biophys. 38 (2003) 1-22. 